\title{
Hedge funds as a diversification vehicle ${ }^{\text {th }}$
}

\author{
Andreas Mikkelsen ${ }^{\mathrm{a}, \mathrm{b}, *}$, Frode Kjærland ${ }^{\mathrm{c}, \mathrm{b}}$, Tom Erik Sønsteng Henriksen ${ }^{\mathrm{d}}$ \\ ${ }^{a}$ UiT The Arctic University of Norway, School of Business and Economics, Follumsvei 39, 9510 Alta, \\ Norway \\ ${ }^{b}$ Nord University Business School, 8049 Bodø, Norway \\ ${ }^{c}$ NTNU Business School, Norwegian University of Science and Technology, 7491 Trondheim, Norway \\ ${ }^{d}$ School of Economics and Business, Norwegian University of Life Sciences, PO Box 5003, 1432 As, \\ Norway
}

\footnotetext{
${ }^{\sqrt{4}}$ We would like to thank an anonymous referee for helpful suggestions improving the paper.

${ }^{*}$ Corresponding author. Andreas Mikkelsen is an Associate Professor at the School of Business and Economics, UiT The Arctic University of Norway. Frode Kjærland is a Professor at NTNU Business School. Tom Erik Sønsteng Henriksen is a PhD candidate at NMBU Business School.

Email addresses: andreas.mikkelsen@uit.no (Andreas Mikkelsen), frode.kjarland@ntnu.no (Frode Kjærland), tom.erik.sonsteng.henriksen@nmbu.no (Tom Erik Sønsteng Henriksen)
} 


\title{
'Hedgefunds as a diversification vehicle'
}

\begin{abstract}
In this study, we evaluate the out-of-sample diversification benefits of including hedge fund indices in global stock-bond portfolios. We investigate this topic by evaluating several asset allocation strategies in the period from 1998 to 2016.

Interestingly, our findings show, in general, no significant increase in performance when we include hedge funds in a portfolio, compared to a well-diversified portfolio as a benchmark. We observe a certain degree of risk reduction when including hedge funds in the portfolio, but the performance does not improve significantly, on average. We extend the literature on portfolio performance when including hedge funds in a multi-asset portfolio, using more asset allocation strategies and a comprehensive dataset, compared to previous studies.
\end{abstract}

Keywords: Finance, Asset Allocation, Hedge funds, Diversification, Performance evaluation.

\section{JEL Classification: G11}

March 27, 2019. 


\section{Introduction}

This study investigates the out-of-sample effect of including hedge fund (HF) investments in a portfolio consisting of global stocks and bonds, by using several asset allocation techniques.

After the financial crisis of 2008, the financial industry transitioned from promising high returns to adopting a greater degree of risk management and diversification (Roncalli, 2013). It is well-known that the risk-adjusted performance of a portfolio can be improved by diversification across imperfectly correlated assets. However, the study observes an increased cross-country co-movement of equity and fixed income returns, since the late 1990s, mainly driven by cross-country correlations of discount rate shocks and/or global capital markets integration (Viceira et al., 2017).

Investors may also improve diversification by including in their portfolios alternative investments with low co-movement of equities and bonds. Both commodities and real estate are said to have low correlation with stocks and bonds and tend to be inflation hedgers. However, literature does not present a consensus on the diversification benefits of commodities due to the low returns and increased co-movement of equities around 2008 (e.g. for a discussion, refer to Erb and Harvey, 2006; Irwin and Sanders, 2011; Basak and Pavlova, 2016; Bhardwaj et al., 2016). Concerning real estate, there is evidence of a low correlation between private real estate and mixed-asset portfolios, but listed real estate stocks correlate strongly with the general stock market. The drawback of private real estate investment is the low liquidity and uncertainty of the duration and outcome of the sales process, which add an extra risk factor to the asset. Furthermore, the correlation varies over time and increases in turmoil (refer to Norges Bank Investment Management, 2015 for a review of real estate diversification potential).

Another way to possibly increase diversification benefits is to include HFs in the portfolio. With few constraints associated with the investment style, HF managers can follow a broad variety of strategies. However, as with commodities and real estate, literature does not present a clear consensus about whether to invest in HF. The returns generated by HF from 2009 to 2016 was heavily outperformed by the S\&P500, and July 2016 witnessed the largest withdrawal from HF since the global financial crisis (GFC), with HF redemptions amounting to $\$ 25.2$ billion. ${ }^{1}$ However, the standard deviation (SD) of the HFRI Asset Weighted Composite Index was substantially lower than that for the S\&P500, which gave the HFRI index a Sharpe ratio that was 37\% higher than the S\&P500 index (Brown, 2016). It is worth mentioning that this index is a diversified index and that a standalone HF may not provide the same risk/return properties.

Another notable factor is that the term 'hedge fund' does not imply a homogeneous asset class but, rather, describes the way in which the fund is organised. Additionally, this property may give diversified HF strategies favourable returns per unit risk and can thus be positioned in a well-diversified asset portfolio (Brown, 2016).

\footnotetext{
${ }^{1}$ WwW.bloomberg.com/news/articles/2016-08-24/hedge-funds-suffer-biggest-redemptionssince-2009-as-returns-lag.
} 
Our findings have interesting implications for portfolio construction when assessing whether to include HFs. As indicated above, we do not find any significant increase in performance when introducing HF in a portfolio, on average. However, there are some HF portfolios with significantly higher risk-adjusted performance in certain sub-periods. We extend the literature on portfolio performance when including HFs in a multi-asset portfolio, using more asset allocation strategies and a comprehensive dataset, compared to previous studies.

The remainder of the paper is organised as follows. In section 2, we examine the literature on $\mathrm{HF}$ investments and its diversification properties. In the subsequent section, 3, we describe the data used and the asset allocation strategies and how the strategies are carried out both in-sample and out-of-sample. In the 4 section, we perform an empirical analysis and discuss the results. Section 5 concludes and discusses the implications of our results for portfolio management and $\mathrm{HF}$ as a diversification vehicle.

\section{Literature review}

There are several studies regarding HF performance. General diversification and the performance of the HF industry are elaborated by, for example, Shawky et al. (2012). The study provides insights on why some HFs outperform others upon the introduction of certain dimensions. Other studies examine the return properties in bull versus bear markets, as done by Frydenberg et al. (2017), and suggest that HF managers seem to perform better in bearish markets. One line of research on HF performance is concerned with funds of hedge funds (FOHFs) (Davies et al., 2009). Denvir and Hutson (2006) examine the performance and diversification of several HFs and find, consistent with other studies, that FOHFs appear to underperform. This is despite the fact that FOHFs have characteristics that offset their apparent underperformance because their returns do not suffer from negative skewness - a typical feature of many HF strategies.

Another aspect of these studies is performance measurement. Eling and Schuhmacher (2007) study return data from many HFs and compare the Sharpe ratio with 12 other performance measurements. Despite the fact that HFs deviate significantly from the normal distribution, they find that ranking hedge funds by Sharpe Ratio provides identical ranking when compared to other performance measurements (such as Treynor ratio, Jensens Alpha, Omega, Sortino ratio, Kappa 3, Upside Potential ratio, Calmar ratio, Sterling ratio, Burke ratio, Excess Return on VaR, Modified Sharpe ratio, and Conditional Sharpe ratio). They deal with individual HFs rather than HF indices. Moreover, they analyse both the cases wherein the HF represents the entire investment and wherein HF constitutes a part of the total investment. They conclude that Sharpe Ratio is sufficient to analyse hedge funds, both for stand-alone HFs or when HFs form only a part of an investment. We apply this reasoning in our study. Brooks and Kat (2002) problematise some of the statistical features of HF return studies. It is often found that HF indices exhibit highly unusual skewness and kurtosis properties and first-order serial correlation. They show that although HF indices are highly attractive in mean-variance terms, this is much less the case when skewness, kurtosis, and autocorrelation are taken into account. Hence, Sharpe ratios are expected to overestimate the true risk-return performance of (portfolios containing) HFs. Similarly, the 
mean-variance portfolio analysis is expected to over-allocate to hedge funds and overestimate the attainable benefits from including hedge funds in an investment portfolio. We notice this aspect when interpreting our findings.

However, although the existing literature seems to have emphasised on HF as an investment alternative, there seems to be a lack of focus on shortcomings when presenting the advantages of including hedge funds with an overall multi-asset allocation perspective. Our study is connected to that of Cvitanic et al. (2003), who discuss how large a portion a longterm investor should allocate to $\mathrm{HF}$ along with other asset classes. Among other results, they find that low beta HFs can serve as substitutes for much of the risk-free placements in larger portfolios. Another study, Haglund (2010), examines the use of higher moment betas to examine the effects of the addition of HFs to an equity portfolio on portfolio volatility, skewness, and kurtosis. The finding is that HFs lower the volatility, skewness, and kurtosis of the portfolio - however the effect is heavily related to the type of HF strategy. Convertible arbitrage, equity market neutral, fixed income arbitrage, merger arbitrage and macro are identified as the most attractive strategies.

Our study is more in line with Haglund (2010). However, we use a different approach than that adopted in the study and relate our portfolios, including HF, to a broader benchmark portfolio - instead of viewing $\mathrm{HF}$ as a diversification vehicle for only equity investors.

Since the returns of alternative investment strategies exhibit, in general, a low correlation with that of standard asset classes, the hedge funds are expected to occupy a significant share in active allocation strategies. While in its infancy, the plethora of alternative investment strategies consisted of a disparate set of managers following very specific strategies. Significant attempts have been made to structure the industry over the last decade that have resulted in allowing the application of active asset allocation models to HFs and traditional investment vehicles. Particularly, investable portfolios replicating broad-based HF indices are available with a sufficient level of liquidity. In this study, we apply the model developed in Cvitanic et al. (2003) to a database of hedge funds. Our results have important implications for investors who consider including alternative investment vehicles in their portfolios. Particularly, they suggest that low beta HFs may serve as natural substitutes for a significant portion of investor risk-free asset holdings. Since the model we use can be generalised in several directions, this study attempts to provide money managers with a tool to allocate assets among HFs.

\section{Data and descriptive statistics}

Our data set consists of monthly prices from January 1998 to December 2016, that is, 228 (227) observations for price levels (returns). We use 3 stock and bond indices and 9 different HF indices. The list of indices used are provided in Exhibit 1.

The HF data set consists of indices provided by the Hedge Fund Research (HFR). The indices are value-weighted, net of transaction costs and fees, and survivorship bias-free. In order for a fund to be included in HFRs indices, it must be an open-ended fund, active for

more than 2 years, and listed in USD. HFR classifies hedge fund strategies into the following five categories: equity hedge, event-driven, macro, relative value, and fund of funds; each 
Exhibit 1: Description of stock, bond and hedgefund indices

\begin{tabular}{ll}
\hline Index & Abbreviation \\
\hline Stock indices & \\
Standard and Poor's Global Small Cap & Small Cap \\
Standard and Poor's Global Mid Cap & Mid Cap \\
Standard and Poor's Global Large Cap & Large Cap \\
& \\
Bond indices & \\
Bloomberg Barclays Global Aggregate & Barclays Global \\
Bloomberg Barclays Global High Yield & US High Yield \\
Bloomberg Barclays US Mortgage Backed Securities & US MBS \\
Hedgefund indices & \\
HFRX Global Hedge Fund Index & Global Hedgefund \\
HFRX Equity Hedge Index & Equity Hedge \\
HFRX EH Equity Market Neutral Index & Equity Market Neutral \\
HFRX Macro/CTA Index & Macro Strategy \\
HFRX Event Driven Index & Event Driven \\
HFRX ED Merger Arbitrage Index & Merger Arb \\
HFRX ED Distressed Securities Restructuring Index & Distressed \\
HFRX Relative Value Arbitrage Index & Relative Value \\
HFRX RV: FI-Convertible Arbitrage Index & Conv. Arb \\
\hline
\end{tabular}


of the five categories has sub-categories. Additionally, the strategies, including the substrategies, are aggregated in the index 'Global Hedge Fund Index', which represents the hedge fund universe. Our sample includes the following:

- the global hedge fund index

- the equity hedge index, including its equity market neutral sub-index.

- the event-driven index, with its sub-indices distressed/ restructuring and merger arbitrage.

- the macro index.

- the relative value index, including its fixed income subindex - convertible arbitrage.

Thus, we include four of the five styles, including four sub-indices of these. As benchmarks for the global stock market, we use three S\&P500 indices, investing in small, medium, and large capitalisation stocks. Thus, we account for different characteristics, that is, for smalland large-cap stocks. Concerning bond investments, we include three bond indices. The Barclays Global Aggregate index is a 'flagship' benchmark on global investment grade bonds from both developed and emerging markets. The Barclays US Mortgage Backed Security index tracks the US real estate market. Finally, the Barclays Global High Yield index tracks global high yield bonds. All index values are total returns and denominated in USD.

The descriptive statistics are presented in Exhibit 2. The three equity indices consisting of small, big, and large capitalization equities have annualised returns ranging from $6.7 \%$ for the large capitalization to roughly $9.7 \%$ for the small capitalization. The risk exposure is similar for the three indices, the small capitalization being the riskiest with an annualised SD of $19 \%$, and the large capitalization with an SD of $17 \%$, which is as per expectations. The indices are highly correlated, and all correlations are above 0.93 . Hence, for brevity, we only show the large capitalization index in the correlation matrix presented in Exhibit 3. All the equity indices are negatively skewed and leptokurtic, the series are tested for normality using the Jarque-Bera test at a 5\% significance level, and normality is rejected in all cases.

Of the bonds, the characteristics of the high-yield index are similar to that of the equity indices, the correlation (not shown) is between 0.70-0.75. It is relatively risky, with an annualised SD of roughly 10\%, and its average annualised return is $7.9 \%$. The higher moments are more profound, with a larger negative skewness and about 4.5 times higher kurtosis than the equity indices; normality is also rejected for this index. The remaining bond indices have practically identical annualised returns, $4.92 \%$, and similar SD, 2.5-2.7\%. However, they do differ in the higher moments in that Barclays Global Aggregate Index is slightly negatively skewed, while the US MBS index is slightly positively skewed. Further, the excess kurtosis is higher, at 2.1 for the latter. Of the two, the former is found to have normally distributed returns, as the only index in our sample. Both indices are slightly negatively correlated, -0.07 to -0.13 , with the equity indices.

Finally, we consider the hedge funds, which is quite a heterogeneous group. The average annual return for the hedge fund indices varies from $0.96 \%$ for the market neutral index to 
Exhibit 2: Descriptive statistics of the stock, bond, and hedge fund indices. Full sample (227 observations), unadjusted time series. The extreme values (Min. and Max. \%) are on monthly scale, while the mean and SD are annualised from monthly observations.

\begin{tabular}{llllllll}
\hline & Min. (\%) & Max. $(\%)$ & Mean $(\%)$ & SD $(\%)$ & Skewness & Excess kurtosis & Normality? \\
\hline Small Cap & -22.89 & 15.43 & 9.72 & 19.09 & -0.63 & 1.93 & No \\
Mid Cap & -22.01 & 16.13 & 8.52 & 18.05 & -0.57 & 2.23 & No \\
Large Cap & -18.98 & 15.76 & 6.72 & 17.08 & -0.42 & 1.53 & No \\
Barclays Global & -2.06 & 2.71 & 4.92 & 2.74 & -0.22 & 0.16 & Yes \\
US MBS & -1.87 & 3.93 & 4.92 & 2.56 & 0.11 & 2.1 & No \\
High Yield & -18.64 & 10.89 & 7.92 & 10.36 & -1.67 & 10.3 & No \\
Global Hedgefund & -9.35 & 5.95 & 4.56 & 6.13 & -0.61 & 5.33 & No \\
Distressed & -11.69 & 6.11 & 3.36 & 7.21 & -1.39 & 6.11 & No \\
Relative Value & -14.11 & 6.81 & 3.36 & 6.62 & -2.72 & 17.38 & No \\
Merger Arb & -4.56 & 3.29 & 5.4 & 3.36 & -1.1 & 3.92 & No \\
Macro Strategy & -7.38 & 8.54 & 4.8 & 8 & 0.44 & 1.79 & No \\
Equity Market Neutral & -3.78 & 2.92 & 0.96 & 3.81 & -0.36 & 0.59 & No \\
Equity Hedge & -9.99 & 9.78 & 5.16 & 8.04 & -0.32 & 3.43 & No \\
Event Driven & -9.02 & 4.79 & 4.8 & 6.69 & -1.34 & 3.8 & No \\
Conv. Arb & -34.68 & 6.74 & 1.8 & 10.63 & -7.32 & 75.39 & \\
\hline
\end{tabular}

$5.4 \%$ in the merger arbitrage. In general, the hedge fund indices have a lower average annual return than the stock and bond indices. However, the SD and downside risk are lower for the hedge funds when compared to the equity indices. The SDs range from $10.63 \%$ (convertible arbitrage) to $3.36 \%$ (merger arbitrage). The convertible and relative arbitrages display fatter tails and a left-skewed distribution than the other indices. The correlations in Exhibit 3 exhibit a low correlation between HF and the stock and bond indices. The distressed, equity market neutral, and the event-driven indices also exhibit a negative correlation with the bond index.

From Exhibit 2 and 3, we observe that the HF has positive returns, relatively low volatility than stocks, and a low correlation with the stock and bond markets. This indicates in-sample diversification benefits when including the HF indices in a stock-bond portfolio.

\subsection{Methods and asset allocation strategies}

In this section, we provide an explanation of the asset allocation procedure and techniques used. We use a 'rolling window' procedure where we estimate the parameters needed for the asset allocations based on the previous 36-month returns (as in DeMiguel et al., 2009). In this study, we omit short-selling and leverage since some investors do not have the mandate to practice it. Furthermore, financial gearing adds another dimension of risk for the investor, and the maximum Sharpe portfolio tends to incorporate extreme values in the asset positions when short-selling is allowed. Finally, the portfolios are long-only; this allows a comparison of portfolio performance because both risk parity and fixed-weighted portfolios have nonnegative weights.

As seen from the skewness and excess kurtosis in Exhibit 2, all assets, except the global 
Exhibit 3: A selection of correlations between stock, bond, and HF indices. Some indices are omitted due to space considerations.

\begin{tabular}{|c|c|c|c|c|c|c|c|c|}
\hline & $\begin{array}{r}\text { Large } \\
\text { Cap }\end{array}$ & $\begin{array}{r}\text { Barclays } \\
\text { Global }\end{array}$ & $\begin{array}{l}\text { Global } \\
\text { Hedge- } \\
\text { fund }\end{array}$ & Distressed & $\begin{array}{c}\text { Merger } \\
\text { Arbi- } \\
\text { trage }\end{array}$ & $\begin{array}{r}\text { Macro } \\
\text { Strategy }\end{array}$ & $\begin{array}{l}\text { Equity } \\
\text { Market } \\
\text { Neutral }\end{array}$ & $\begin{array}{r}\text { Event } \\
\text { Driven }\end{array}$ \\
\hline Barclays Global & -0.09 & & & & & & & \\
\hline Global Hedgefund & 0.58 & 0.04 & & & & & & \\
\hline Distressed & 0.41 & -0.13 & 0.56 & & & & & \\
\hline Merger Arb & 0.40 & 0.04 & 0.41 & 0.30 & & & & \\
\hline Macro Strategy & 0.15 & 0.17 & 0.64 & 0.09 & 0.18 & & & \\
\hline Equity Market Neutral & 0.02 & -0.10 & 0.11 & 0.14 & 0.27 & 0.04 & & \\
\hline Event Driven & 0.63 & -0.13 & 0.76 & 0.67 & 0.57 & 0.24 & 0.16 & \\
\hline Conv. Arb & 0.40 & 0.04 & 0.62 & 0.58 & 0.25 & 0.11 & 0.00 & 0.56 \\
\hline
\end{tabular}

bond index, have non-normal distributed returns. Most of the assets exhibit leptokurtosis and negative skewness, and hence the SD as a risk measure is expected to underestimate the true risk of an asset (Inker, 2011). This highlights the importance of using alternative risk measures. We incorporate this finding in the asset allocation strategies by employing both SD and a 5\% modified expected tail loss (ETL) as risk measures (denoted $\psi$ ) in the portfolio optimisation. The ETL measure satisfies the conditions for a coherent risk measure (see e.g. Artzner et al. 1999). ${ }^{2}$ For the ETL procedure, we use the Cornish-Fisher approximation because this approach accounts for the higher moments of the distribution. The procedure of the ETL calculations is based on Boudt et al. (2008), implemented in the R package PerformanceAnalytics by Peterson and Carl (2018a). For the optimisation implementation we rely on the $\mathrm{R}$ package PortfolioAnalytics by Peterson and Carl (2018b), using the differential evolution algorithm by Ardia et al. (2011) for the optimisation. For a review on reward-risk optimisation problems where different choices of reward and risk measures are considered, see e.g. Stoyanov et al. (2007).

\subsubsection{Equally Weighted}

This strategy involves holding a portfolio weight $w_{t}^{e w}=1 / N$ in each of the $\mathrm{N}$ assets. This strategy does not involve any optimisation or estimation and completely ignores the data. DeMiguel et al. (2009) found that other optimised asset allocation techniques are not consistently better than the $1 / \mathrm{N}$ rule, based on several performance measures. The same results are proven by Pflug et al. (2012).

\subsubsection{Strategic Weighted}

In this allocation, we will compare a $70 \% / 30 \%$ stock-bond portfolio to a $70 \% / 25 \% / 5 \%$ stock-bond-HF portfolio. ${ }^{3}$ This is an ad-hoc portfolio choice; however, holding a portfolio of only risky assets will result in a portfolio that is beyond the risk appetite of many investors .

\footnotetext{
${ }^{2} \mathrm{~A}$ random variable is called a coherent risk measure if it is: monotonous, sub-additive, positively homogeneous and translation invariant.

${ }^{3}$ The asset classes in the sub-portfolios are equally weighted.
} 
In such, several investors want to have a stable element like bonds that give an opportunity to buy more risky assets when these are low. The allocation weights chosen are similar to Norges Bank Investment Management's allocations, but we will replace the real estate by hedge fund investments. ${ }^{4}$ Our weighting scheme in the strategic portfolio is also in line with other articles on the topic (e.g. refer to Bessler and Wolff, 2015).

\subsubsection{Reward-to-Risk Timing}

The reward-to-risk timing (RRT) allocation technique was proposed by Kirby and Ostdiek (2012), and we set the portfolio weights based on the reward-to-risk ratio, which is the sample mean return divided by the sample variance of an asset. The asset allocation technique is inspired by the momentum strategy, given that funds performing well in the current period are given higher portfolio weights in the next period.

$$
w_{i}^{r r t}=\frac{\max \left(\hat{\mu}_{i}, 0\right) / \hat{\psi}_{i}^{(2)}}{\sum_{i=1}^{N} \max \left(\hat{\mu}_{i}, 0\right) / \hat{\psi}_{i}^{(2)}}
$$

When using ETL as a risk measure in this allocation, the risk measure will not be squared. Furthermore, we assume equally weighted portfolio when all sample returns are negative.

\subsubsection{Equal Risk Contribution}

The idea of equal risk contribution (ERC) or risk parity is inspired by Booth and Fama (1992), who mention the risk contribution of an asset in the context of a multi-class allocation. However, Qian (2005) was the first study to mention 'risk parity'. The study argued the need to diversify on the basis of risk rather than weights, as in the $1 / \mathrm{N}$ portfolio. The low volatility anomaly leads to an increase in popularity for this allocation strategy (Ang et al., 2006, Blitz and van Vliet, 2007, and Jordan and Riley, 2015). Additionally, according to these studies, the expected risk to return relationship is flat rather than positive, as would be expected from standard theory. Thus, an investor gains a higher risk adjusted return when holding assets with low volatility. When the risk contribution of each portfolio component is made equal, it is mathematically defined as:

$$
w_{i} \times \frac{\delta \psi_{p}}{\delta w_{i}}=w_{j} \times \frac{\delta \psi_{p}}{\delta w_{j}} \quad \forall i, j \text { and } i \neq j
$$

When modified ETL are used as a risk measure, the decomposition of the risk follows Boudt et al. (2008).

For the optimisation, we will follow the objective function provided by Maillard et al. (2010). The procedure minimises the sum of squared differences between the assets' risk contributions and by that finding the weights that makes the risk contributions across individual

\footnotetext{
${ }^{4}$ For NBIM strategy and allocations, refer to https://www.nbim.no/en/organisation/strategyplan/.
} 
assets equal. The optimisation is then given by:

$$
\min f(w)=\sum_{i=1}^{N} \sum_{j=1}^{N}\left[w_{i} \times \frac{\delta \psi_{p}}{\delta w_{i}}-w_{j} \times \frac{\delta \psi_{p}}{\delta w_{j}}\right]^{2} \quad \forall \quad i, j \text { and } i \neq j
$$

where $w_{i}$ are a unique solution and the condition $f\left(w_{i}\right)=0$ is ensured. Since $w_{i}$ is a function of the risk contribution, which again depends on $w_{i}$, there is a problem of endogeneity that is taken into account in this optimisation algorithm.

\subsubsection{Minimum Risk}

The Global Minimum Risk portfolio (minRisk) employs the portfolio weights that minimise the in-sample portfolio risk. The objective function is given by:

$$
\min \psi_{p} \quad \text { s.t. } \quad \sum_{i=1}^{N} w=1 \text { and } 0 \leq w_{i} \leq 1
$$

where $w_{i}$ is the weight of asset $i, \psi_{p}$ is the risk of the portfolio $p$.

\subsubsection{Maximum Sharpe Ratio}

The maximum Sharpe ratio (maxSR), also called the 'tangency portfolio' is given by:

$$
\max \frac{\overline{r_{p}}-r_{f}}{\psi_{p}} \quad \text { s.t. } \sum_{i=1}^{N} w=1 \text { and } 0 \leq w_{i} \leq 1
$$

Where $\overline{r_{p}}$ is the portfolio average return, $r_{f}$ is the average risk-free rate, and $\psi_{p}$ is the portfolio risk. Estimation errors in the input parameters can lead to poor performance of maxSR portfolios (Best and Grauer, 1991). Some researchers, such as Chopra and Ziemba (2011), argue that estimation errors in return estimates dominate errors in the covariance.

\subsubsection{Return smoothing}

Several studies, such as (Brown et al., 2012, Cavenaile et al., 2011, Gallais-Hamonno and Nguyen-Thi-Thanh, 2008, Getmansky et al., 2004), argue that HF returns are 'smoothed', meaning that they appear 'smoother' than the true economic returns. This is due to, for example, illiquid fund holdings, where market prices are not readily available; this is true, for instance, when investing in real estate. Further, when fund managers price illiquid holdings, they may have incentives to optimise returns, with regards to the funds benchmark index. This may be a concern, especially, for the hedge fund industry that is less-regulated and transparent when compared to the mutual funds that are more regulated. The result of the return smoothing is a downward bias in return variance, leading to inflated Sharpe ratios and a positive auto-correlation.

$$
\begin{gathered}
X_{t}=R_{t}^{o}-\mu \\
X_{t}=\theta_{0} \eta_{t}+\theta_{1} \eta_{t-1}+\ldots+\theta_{k} \eta_{t-k}
\end{gathered}
$$




$$
\begin{gathered}
1=\theta_{0}+\theta_{1}+\ldots+\theta_{k} \\
R_{t}^{c}=\frac{R_{t}^{o}-\hat{\theta}_{1} R_{t-1}^{c}-\ldots-\hat{\theta}_{k} R_{t-k}^{c}}{\hat{\theta}_{0}}
\end{gathered}
$$

Getmansky et al. (2004) proposes an economic model to 'unsmooth' the returns. In this framework, the original return series becomes 'unsmoothed'; this procedure removes the auto-correlation and the downward-biased return volatility, while the expected returns of the series remain unchanged. This is operationalised in several steps, which will be explained in the following section. First, we demean the original time series $R_{t}^{o}$ and denote the demeaned HF return series $X_{t}$, as shown in Equation 6. Subsequently, the demeaned time series is modelled as an MA(q) process, for which the number of lags (q) in the model is determined by the BIC criterion, as shown in Equation 7. Subsequently, the parameters are constrained to sum up to 1; this means that, eventually, all information will be reflected in the series, but that it may be take up to $\mathrm{q}+1$ periods after the information is generated, before it is incorporated in the observed price, as shown in Equation 8. To ensure that the parameters are constrained to 1 , we divide the estimates by $\left(1+\theta_{0}+\ldots+\theta_{k}\right)$ and assume that the original estimate of $\theta_{0}$ is 1 . Finally, Gallais-Hamonno and Nguyen-Thi-Thanh (2008) shows that we may rearrange the return equation to retrieve the 'true' returns series $R_{t}^{c}$ from the original time series. The expected return of the 'true' return series is equal to that of the original return series, but, as already mentioned, the return does not suffer from auto-correlation and downward biased return volatility because of an unsmoothing, as shown in Equation 9. A smoothing index is presented in Exhibit 4; the index is the sum of the squared parameters from Equation 8. The smoothing index can be interpreted as follows. A high value, close to unity, represents little return smoothing, while a low value represents a higher degree of return smoothing. Thus, a return series with a low smoothing index has a high degree of auto-correlation and a downward bias in the return volatility.

The estimated parameters from Equation 8 is shown in Exhibit 4. We recall that a smoothing index near unity means that the time series is not plagued with auto-correlation and downward biased return volatility; this is true for the macro strategy index. Hedge funds' constituents, in this index, are primarily attempting to predict the future movements and impacts in underlying securities.

\section{Empirical results}

As previously mentioned, our empirical setting is constructed on a 3-year portfolio formation period, while the portfolios are re-balanced twice a year. The length of the periods is chosen arbitrarily. For robustness, we also consider other formation and re-balancing periods. When considering the length of the formation period, there is a balance between having enough data and ensuring that the oldest data points are representative of current market conditions. With regards to re-balancing, it is sensible not to frequently re-balance when considering transaction costs. Semi-annual re-balancing is common in the industry, 
Exhibit 4: Estimated $\theta$ s and smoothing indices using the GLM approach

\begin{tabular}{lccccc}
\hline & $\theta_{0}$ & $\theta_{1}$ & $\theta_{2}$ & $\theta_{3}$ & $\begin{array}{c}\text { Smoothing } \\
\text { index }\end{array}$ \\
\hline Global Hedgefund & 0.77 & 0.23 & & & 0.64 \\
Distressed & 0.56 & 0.25 & 0.10 & 0.09 & 0.40 \\
Relative Value & 0.57 & 0.31 & 0.13 & & 0.43 \\
Merger Arb & 0.85 & 0.15 & & & 0.74 \\
Macro Strategy & 1.00 & & & & 1.00 \\
Equity Market Neutral & 0.84 & 0.16 & & & 0.73 \\
Equity Hedge & 0.65 & 0.15 & 0.11 & 0.09 & 0.46 \\
Event Driven & 0.68 & 0.24 & 0.08 & & 0.53 \\
Conv. Arb & 0.53 & 0.34 & 0.13 & & 0.42 \\
\hline
\end{tabular}

Note: The smoothing indices are the sum of the squared $\theta s$

wherein, for instance, a selection of Blackrock ETFs is re-balanced semi-annually. For robustness tests, we vary the formation period to 1 and 2 years and yearly re-balancing for all formation periods, in addition to semi-annual re-balancing.

In Exhibit 5, the annualised return, volatility, and performance measures are presented. The portfolios, including an HF, which perform better than the baseline stock-bond portfolio are highlighted in bold in the exhibit. We observe that, in general, we could not improve the portfolio returns by including HFs. In four of the six allocation strategies, the base stockbond portfolio yields the highest average return. In the two cases, minRisk and maxSR strategies, we could improve returns in $30 \%$ and $10 \%$ of the portfolios. In both the cases, the improvement is marginal, at best $0.13 \%$ for the former and $0.19 \%$ for the latter. 
Exhibit 5: Out-of-sample portfolio returns using uadjusted returns and SD as a risk metric. The portfolios, including HFs, that have a larger return, lesser volatility, or higher Sharpe ratio than the stock-bond portfolio, are highlighted in bold. If the stock-bond portfolio performs better than the portfolios including HFs, then it is marked in bold.

\begin{tabular}{|c|c|c|c|c|c|c|c|c|c|c|c|c|}
\hline \multirow[b]{2}{*}{$\begin{array}{l}\text { Asset } \\
\text { Allocation } \\
\text { Strategy }\end{array}$} & \multirow[b]{2}{*}{$\begin{array}{l}\text { Performance } \\
\text { Measure }\end{array}$} & \multirow[b]{2}{*}{$\begin{array}{l}\text { Stock- } \\
\text { Bond } \\
\text { Portfolio }\end{array}$} & \multicolumn{10}{|c|}{ Stock-bond portfolio including hedgefunds } \\
\hline & & & $\begin{array}{l}\text { Global } \\
\text { Hedge- } \\
\text { funds }\end{array}$ & $\begin{array}{l}\text { Convertible } \\
\text { Arb. }\end{array}$ & Distressed & $\begin{array}{l}\text { Equity } \\
\text { Hedge }\end{array}$ & $\begin{array}{l}\text { Equity } \\
\text { Market } \\
\text { Neutral }\end{array}$ & $\begin{array}{l}\text { Event } \\
\text { Driven }\end{array}$ & $\begin{array}{l}\text { Macro } \\
\text { Strategy }\end{array}$ & $\begin{array}{l}\text { Merger } \\
\text { Arb }\end{array}$ & $\begin{array}{l}\text { Relative } \\
\text { Value }\end{array}$ & All \\
\hline \multirow{4}{*}{ minRisk } & $\begin{array}{l}\text { Average } \\
\text { return }\end{array}$ & 4.43 & 4.11 & 4.14 & 4.18 & 4.47 & 3.38 & 4.56 & 4.32 & 4.48 & 3.71 & 4 \\
\hline & $\mathrm{SD}$ & 2.66 & 2.71 & 2.76 & 2.63 & 2.65 & 2.33 & 2.57 & 2.58 & 2.33 & 2.54 & 2.12 \\
\hline & Sharpe ratio & 1.67 & 1.52 & 1.5 & 1.59 & 1.68 & 1.45 & 1.77 & 1.67 & 1.92 & 1.46 & 1.88 \\
\hline & $\begin{array}{l}\text { Modified } \\
\text { Sharpe }\end{array}$ & 0.7 & 0.5 & 0.62 & 0.54 & 0.76 & 0.58 & 0.92 & 0.82 & 0.99 & 0.57 & 0.96 \\
\hline \multirow{4}{*}{$\mathrm{RP}$} & $\begin{array}{l}\text { Average } \\
\text { return }\end{array}$ & 5.1 & 4.67 & 4.32 & 4.58 & 4.72 & 3.78 & 4.84 & 4.57 & 4.86 & 4.48 & 3.14 \\
\hline & $\mathrm{SD}$ & 3.76 & 3.54 & 4.13 & 3.58 & 3.6 & 2.71 & 3.55 & 3.51 & 3.24 & 3.6 & 2.81 \\
\hline & Sharpe ratio & 1.35 & 1.32 & 1.05 & 1.28 & 1.31 & 1.39 & 1.36 & 1.3 & 1.5 & 1.24 & 1.12 \\
\hline & $\begin{array}{l}\text { Modified } \\
\text { Sharpe }\end{array}$ & 0.37 & 0.34 & 0.21 & 0.28 & 0.36 & 0.46 & 0.38 & 0.39 & 0.43 & 0.27 & 0.22 \\
\hline \multirow{4}{*}{$\operatorname{maxSR}$} & $\begin{array}{l}\text { Average } \\
\text { return }\end{array}$ & 4.76 & 4.13 & 4.5 & 4.66 & 4.26 & 4.04 & 4.95 & 4.26 & 4.69 & 4.18 & 4.1 \\
\hline & $\mathrm{SD}$ & 2.85 & 2.7 & 3.04 & 2.74 & 2.68 & 2.5 & 2.72 & 3.04 & 2.68 & 2.8 & 2.29 \\
\hline & Sharpe ratio & 1.67 & 1.53 & 1.48 & 1.7 & 1.59 & 1.61 & 1.82 & 1.4 & 1.75 & 1.49 & 1.79 \\
\hline & $\begin{array}{l}\text { Modified } \\
\text { Sharpe }\end{array}$ & 0.58 & 0.6 & 0.67 & 0.57 & 0.77 & 0.86 & 0.94 & 0.45 & 0.78 & 0.41 & 0.95 \\
\hline \multirow{4}{*}{ RRT } & $\begin{array}{l}\text { Average } \\
\text { return }\end{array}$ & 4.6 & 4.27 & 4.4 & 4.28 & 4.34 & 4.28 & 4.35 & 4.53 & 4.47 & 4.1 & 3.56 \\
\hline & $\mathrm{SD}$ & 3.5 & 3.47 & 3.58 & 3.45 & 3.5 & 3.19 & 3.49 & 3.46 & 3.04 & 3.38 & 3.1 \\
\hline & Sharpe ratio & 1.31 & 1.23 & 1.23 & 1.24 & 1.24 & 1.34 & 1.25 & 1.31 & 1.47 & 1.21 & 1.15 \\
\hline & $\begin{array}{l}\text { Modified } \\
\text { Sharpe }\end{array}$ & 0.34 & 0.29 & 0.26 & 0.26 & 0.3 & 0.37 & 0.31 & 0.35 & 0.38 & 0.26 & 0.22 \\
\hline \multirow{4}{*}{ EW } & $\begin{array}{l}\text { Average } \\
\text { return }\end{array}$ & 7.09 & 6.4 & 6.19 & 6.48 & 6.36 & 6.15 & 6.56 & 6.44 & 6.64 & 6.4 & 4.33 \\
\hline & $\mathrm{SD}$ & 10.34 & 9.4 & 9.79 & 9.38 & 9.61 & 8.86 & 9.52 & 9 & 9.09 & 9.47 & 6.49 \\
\hline & Sharpe ratio & 0.69 & 0.68 & 0.63 & 0.69 & 0.66 & 0.69 & 0.69 & 0.71 & 0.73 & 0.67 & 0.67 \\
\hline & $\begin{array}{l}\text { Modified } \\
\text { Sharpe }\end{array}$ & 0.24 & 0.23 & 0.16 & 0.22 & 0.22 & 0.24 & 0.24 & 0.25 & 0.26 & 0.21 & 0.16 \\
\hline \multirow{4}{*}{ s.w. } & $\begin{array}{l}\text { Average } \\
\text { return }\end{array}$ & 7.29 & 7.1 & 7.03 & 7.13 & 7.09 & 7.02 & 7.16 & 7.12 & 7.19 & 7.1 & 7.1 \\
\hline & $\mathrm{SD}$ & 11.84 & 11.89 & 11.99 & 11.87 & 11.96 & 11.7 & 11.93 & 11.74 & 11.78 & 11.91 & 11.86 \\
\hline & Sharpe ratio & 0.62 & 0.6 & 0.59 & 0.6 & 0.59 & 0.6 & 0.6 & 0.61 & 0.61 & 0.6 & 0.6 \\
\hline & $\begin{array}{l}\text { Modified } \\
\text { Sharpe }\end{array}$ & 0.22 & 0.21 & 0.2 & 0.21 & 0.21 & 0.22 & 0.22 & 0.22 & 0.22 & 0.21 & 0.21 \\
\hline
\end{tabular}


Regarding volatility, on the other hand, we find that, in five out of the six allocation strategies, the HF portfolios are less risky in at least $80 \%$ of the portfolios. In the case of an equally weighted portfolio, all the HF portfolios are found to be less risky than the base portfolio. The strategically weighted portfolio is an exception, where only $30 \%$ of the portfolios have a lower risk than the base portfolio. Further, we find that, when allowing a combination of all the HF indices in a portfolio, these portfolios represent the lowest risk in three out of the five cases mentioned above. This implies that diversification benefits can be obtained when combining more than one HF style. The reduction in risk varies from $0.14 \%$ for the strategic weighted portfolio to $3.85 \%$ for the equally weighted portfolio.

Naturally, an investor is most interested in the risk-adjusted performance. It is a wellknown stylised fact of HF returns that they are not normally distributed. Hence, we present the modified Sharpe ratios, where we use modified ETL as the risk measure, since this measure also accounts for the higher moments in the distribution. ${ }^{5}$ For the strategic-weighted portfolio, none of the HF portfolios outperforms the base portfolio. The minRisk and maxSR strategies have the highest proportion of HF portfolios, outperforming the base portfolio, with $50 \%$ and $70 \%$, respectively. For the former, the highest modified Sharpe ratio is 0.99 for the merger arbitrage portfolio, compared to 0.7 for the base portfolio, while for the latter, the portfolio containing all the HF indices has a modified Sharpe ratio of 0.95 and the corresponding base portfolio has a modified Sharpe ratio of 0.58. In order to test whether the risk-adjusted performance of the HF portfolios is significantly better than that of the base portfolio, we use the method proposed by Opdyke (2007). The method accounts for the higher moments in the HF and base portfolios and their correlations; we test the difference in the Sharpe ratios. The previously mentioned merger arbitrage portfolio for the minRisk allocation strategy has the highest t-value of all the portfolios, with a t-statistic of 1.32. Hence, we conclude that even though the HF portfolios, in some instances, can generate higher risk-adjusted returns than the base portfolio, they are not significantly different from another on average.

In Exhibit 6, we scrutinise the portfolio weights for the four allocation strategies involving optimisation, when allowing one HF index in the portfolio at a time. Weights that are significant at a $1 \%$ significance level are highlighted in bold in the exhibit. For the minRisk allocation strategy, we observe that all the portfolios have weights that are significantly different from zero. The equity market neutral has the highest average portfolio weight at $32.9 \%$, while the distressed securities have the lowest weight at $7.9 \%$. At the same time, the change in portfolio weights, measured by volatility, is quite large; in all but three cases, the volatility is higher than the average weight. This translates into larger transaction costs, which we have not accounted for, when re-balancing. Further, we see that in the extreme, we allocate up to $92.6 \%$ of our wealth to the HF index, in the case of the merger arbitrage portfolio, a poor strategy when trying to achieve diversification benefits. A more realistic approach might be to put restrictions on the weights of each asset class. However, we have not attempted this in our study. We see similar patterns for the maxSR and RRT

\footnotetext{
${ }^{5}$ The modified Sharpe is given by $\frac{r_{p}-r_{f}}{E T L_{p}}$.
} 
Exhibit 6: HF portfolio weights, when one HF index is allowed in the portfolio at a time. Weights that are significantly different from zero at a $1 \%$ significance level are highlighted in bold. The t-statistics are robust to heteroscedasticity and auto-correlation, as confirmed by the Newey-West method with five lags.

\begin{tabular}{|c|c|c|c|c|c|c|c|c|c|c|}
\hline $\begin{array}{l}\text { Allocation } \\
\text { Strategy }\end{array}$ & Measure & $\begin{array}{l}\text { Global } \\
\text { Hedgef. }\end{array}$ & $\begin{array}{l}\text { Conv. } \\
\text { Arb. }\end{array}$ & $\begin{array}{l}\text { Dist- } \\
\text { ressed }\end{array}$ & $\begin{array}{l}\text { Equity } \\
\text { Hedge }\end{array}$ & $\begin{array}{l}\text { Equity } \\
\text { Mar- } \\
\text { ket } \\
\text { Neutr. }\end{array}$ & $\begin{array}{l}\text { Event } \\
\text { Driven }\end{array}$ & $\begin{array}{l}\text { Macro } \\
\text { Strat. }\end{array}$ & $\begin{array}{l}\text { Merger } \\
\text { Arb }\end{array}$ & $\begin{array}{l}\text { Relative } \\
\text { Value }\end{array}$ \\
\hline \multirow{3}{*}{ minRisk } & Mean (\%) & 9.5 & 14.6 & 7.9 & 9 & 32.9 & 9.6 & 7.9 & 28.4 & 21.6 \\
\hline & $\mathrm{SD}(\%)$ & 11.1 & 16.5 & 8.8 & 9.8 & 18.2 & 9.5 & 9.9 & 25.4 & 21.9 \\
\hline & $\operatorname{Max}(\%)$ & 41.4 & 66 & 31 & 33.8 & 74.8 & 31 & 45.4 & 92.6 & 73.2 \\
\hline \multirow{3}{*}{$\mathrm{RP}$} & Mean (\%) & 12.9 & 15.4 & 13.2 & 10.3 & 28 & 11.3 & 14.7 & 21.9 & 17.6 \\
\hline & $\mathrm{SD}(\%)$ & 3.5 & 6.7 & 3.5 & 3.1 & 6.8 & 1.6 & 6.6 & 6.4 & 7.8 \\
\hline & $\operatorname{Max}(\%)$ & 20.6 & 27.2 & 19.8 & 18.2 & 38.1 & 14.4 & 33.1 & 36.5 & 30.6 \\
\hline \multirow{3}{*}{$\operatorname{maxSR}$} & Mean (\%) & 12.2 & 17.3 & 11.1 & 7.1 & 19.9 & 9.4 & 3.8 & 21.5 & 20.4 \\
\hline & $\mathrm{SD}(\%)$ & 17.4 & 22.9 & 15.7 & 10.1 & 15.4 & 8 & 5.4 & 22.2 & 21.6 \\
\hline & $\operatorname{Max}(\%)$ & 64.2 & 81.2 & 48 & 41.6 & 59.8 & 31.8 & 22.2 & 78.6 & 82.6 \\
\hline \multirow{3}{*}{ RRT } & Mean (\%) & 10.2 & 12.4 & 8 & 7.4 & 6.7 & 8.2 & 4.3 & 22.1 & 16.3 \\
\hline & SD (\%) & 10.4 & 14 & 7.9 & 7.8 & 8 & 6.4 & 4.3 & 12.6 & 16.9 \\
\hline & $\operatorname{Max}(\%)$ & 38.2 & 47.6 & 21.3 & 29.4 & 31.5 & 24.2 & 15.6 & 66.3 & 53.7 \\
\hline
\end{tabular}

strategies; however, for these strategies, the HF weights are not significant for the convertible arbitrage and distressed securities portfolios for the former, and the convertible arbitrage and relative value arbitrage for the latter. The risk parity strategy stands out of the three, while all the weights are significant. We observe much lower volatility in the portfolio weights when compared to the other three allocation strategies, which is beneficial with regards to transaction costs.

The weights for the portfolio where we allow all the HF indices is shown in Exhibit 7 . As expected, the risk parity strategy has significant weights on all the indices, given that we prefer an equal risk contribution from all assets. There is also a low variation in the weights, similar to the case where we have only one HF index in the portfolio. We observe that, for the RRT strategy, two of the indices do not have a significant loading; for the minRisk and maxSR strategies, the corresponding number is $4 / 8$ and $5 / 8$, respectively. Further, the volatility of the portfolio weights for the three allocation strategies increases when compared to their weights, which naturally represents a higher transaction cost for the investor, with frequent re-balancing.

We found that when sorting on SD and using the unadjusted HF returns, we were unable to improve the risk-adjusted performance of the stock-bond portfolio, by adding HF indices. In this section, we use ETL as a risk measure, which accounts for skewness and kurtosis in the distribution. Further, we unsmooth the HF returns in the portfolio selection, using the method of Getmansky et al. (2004), and trade on the unadjusted returns. This estimation allowed us to compare the two methods; the results of this comparison are shown in Exhibit 8. We failed to achieve a higher return than the benchmark in all but one cases. The exception is the maxSR allocation strategy wherein we could improve the returns by $0.33 \%$ when adding 
Exhibit 7: Portfolio weights when allowing all HF indices to be selected in portfolio at the same time. Weights that are significantly different from zero at a $1 \%$ significance level are marked in bold. The t-statistics are robust to heteroscedasticity and auto-correlation, as confirmed by the Newey-West method with five lags.

\begin{tabular}{|c|c|c|c|c|c|c|c|c|c|}
\hline $\begin{array}{l}\text { Allocation } \\
\text { Strategy }\end{array}$ & Measure & $\begin{array}{l}\text { Conv. } \\
\text { Arb. }\end{array}$ & $\begin{array}{l}\text { Dist- } \\
\text { ressed }\end{array}$ & $\begin{array}{l}\text { Equity } \\
\text { Hedge }\end{array}$ & $\begin{array}{l}\text { Equity } \\
\text { Mar- } \\
\text { ket } \\
\text { Neutr. }\end{array}$ & $\begin{array}{l}\text { Event } \\
\text { Driven }\end{array}$ & $\begin{array}{l}\text { Macro } \\
\text { Strat. }\end{array}$ & $\begin{array}{l}\text { Merger } \\
\text { Arb }\end{array}$ & $\begin{array}{l}\text { Relative } \\
\text { Value }\end{array}$ \\
\hline \multirow{3}{*}{ minRisk } & Mean (\%) & 5.9 & 1.9 & 2 & 16.9 & 1.5 & 2.1 & 10.8 & 9 \\
\hline & $\mathrm{SD}(\%)$ & 9.6 & 3.3 & 4.6 & 15.7 & 2.6 & 4 & 17.8 & 14.4 \\
\hline & $\operatorname{Max}(\%)$ & 31.8 & 10.8 & 20.2 & 58.4 & 8.8 & 17 & 73.2 & 49.4 \\
\hline \multirow{3}{*}{$\mathrm{RP}$} & Mean (\%) & 5.9 & 4.8 & 3.4 & 16.3 & 3.7 & 6.5 & 8.9 & 6.4 \\
\hline & $\mathrm{SD}(\%)$ & 2.9 & 1.3 & 1.4 & 5.3 & 0.7 & 3.5 & 3.5 & 3.4 \\
\hline & $\operatorname{Max}(\%)$ & 11.2 & 7.5 & 7.3 & 27.1 & 5.3 & 16.9 & 19.6 & 12.5 \\
\hline \multirow{3}{*}{$\operatorname{maxSR}$} & Mean (\%) & 6.7 & 4.7 & 2.5 & 5.5 & 0.9 & 2.5 & 13 & 9.3 \\
\hline & $\mathrm{SD}(\%)$ & 11 & 7.8 & 6.6 & 8.6 & 1.6 & 3.7 & 22.6 & 17.5 \\
\hline & $\operatorname{Max}(\%)$ & 46.6 & 25.2 & 36.8 & 32.6 & 7.2 & 13.4 & 79.6 & 65.6 \\
\hline \multirow{3}{*}{ RRT } & Mean (\%) & 7.1 & 3.9 & 3.2 & 3.1 & 4 & 1.8 & 15.6 & 9.3 \\
\hline & $\mathrm{SD}(\%)$ & 7.7 & 4 & 3.2 & 3.7 & 3.1 & 1.7 & 12.1 & 9.3 \\
\hline & $\operatorname{Max}(\%)$ & 23.9 & 11.7 & 11.3 & 12.7 & 11 & 5.3 & 54.4 & 31.6 \\
\hline
\end{tabular}

the event driven HF index to the portfolio. Additionally, most of the other portfolios, by using this allocation strategy, exceeded the benchmark. Hence, in our case, we observe that the benefits of HF are slim from a returns perspective.

Haglund (2010) finds that risk benefits can be obtained by including HF in the portfolio. This is also true for all our allocation strategies since there is at least one HF portfolio with lower risk than the base portfolio.

However, the risk reduction is generally modest. The exception is the portfolio that allows for all $\mathrm{HF}$ indices with an EW allocation, which achieves a risk reduction of $3.85 \%$. While, the other portfolios with an EW allocation archieves risk reductions of $0.55 \%$ to $1.48 \%$. For the remaining allocation strategies, the risk reductions are smaller, ranging from $0.71 \%$ to $0.01 \%$. We further note that in all the strategies, except for the strategic weighted allocation strategy, the lowest risk is found in the portfolio containing all the HF indices. Correspondingly, when using unadjusted returns, the portfolio with all the HFs had the lowest risk in only $50 \%$ of the allocation strategies. This indicates that we can better asses risk with unsmoothed returns and when using a risk measure accounting for the higher moments in the distribution; this further implies that diversification benefits can be obtained. This results in a low percentage of HF portfolios with better risk-adjusted performance than the base portfolio. The exception is the maxSR allocation strategy wherein all portfolios have a higher Sharpe ratio and a higher modified Sharpe ratio. For the remainder of the allocation strategies, only 10-50\% of the portfolios outperform the base portfolio, by either ratio. However, in the case of strategic weighted portfolios, none of the HF portfolios outperform the base portfolio. We test whether 
any of the HF portfolio Sharpe ratios are significantly different from the base portfolio, by again using the method proposed by Opdyke (2007). Again, we find no significant outperformance over the base portfolio; the highest t-statistic is 1.37 for the minRisk allocation strategy when allowing all HF indices in the portfolio together. However, there are three portfolios that significantly underperform the base stock-bond portfolio. This means that adding HFs to the portfolio is not risk free. 
Exhibit 8: Out-of-sample portfolios using unsmoothed returns and modified ETL to account for skewness and kurtosis in the portfolio selection. The portfolios, including HFs, that have a larger return, lesser volatility, or higher Sharpe ratio than the stock-bond portfolio, are highlighted in bold. If the stock-bond portfolio performs better than the portfolios including HFs, then it is marked in bold.

\begin{tabular}{|c|c|c|c|c|c|c|c|c|c|c|c|c|}
\hline \multirow[b]{2}{*}{$\begin{array}{l}\text { Asset } \\
\text { Allocation } \\
\text { Strategy }\end{array}$} & \multirow[b]{2}{*}{$\begin{array}{l}\text { Performance } \\
\text { Measure }\end{array}$} & \multirow[b]{2}{*}{$\begin{array}{l}\text { Stock- } \\
\text { Bond } \\
\text { Portfolio }\end{array}$} & \multicolumn{10}{|c|}{ Stock-bond portfolio including hedgefunds } \\
\hline & & & $\begin{array}{l}\text { Global } \\
\text { Hedge- } \\
\text { funds }\end{array}$ & $\begin{array}{l}\text { Convertible } \\
\text { Arb. }\end{array}$ & Distressed & $\begin{array}{l}\text { Equity } \\
\text { Hedge }\end{array}$ & $\begin{array}{l}\text { Equity } \\
\text { Market } \\
\text { Neutral }\end{array}$ & $\begin{array}{l}\text { Event } \\
\text { Driven }\end{array}$ & $\begin{array}{l}\text { Macro } \\
\text { Strategy }\end{array}$ & $\begin{array}{l}\text { Merger } \\
\text { Arb }\end{array}$ & $\begin{array}{l}\text { Relative } \\
\text { Value }\end{array}$ & All \\
\hline \multirow{4}{*}{$\operatorname{minSD}$} & $\begin{array}{l}\text { Average } \\
\text { return }\end{array}$ & 4.93 & 4.46 & 4.42 & 4.51 & 4.55 & 4.38 & 4.45 & 4.66 & 4.72 & 4.79 & 4.49 \\
\hline & $\mathrm{SD}$ & 2.69 & 2.55 & 3.27 & 2.95 & 2.68 & 2.33 & 2.83 & 2.73 & 2.61 & 2.64 & 2.14 \\
\hline & Sharpe ratio & 1.83 & 1.75 & 1.35 & 1.53 & 1.7 & 1.88 & 1.57 & 1.7 & 1.81 & 1.81 & 2.1 \\
\hline & $\begin{array}{l}\text { Modified } \\
\text { Sharpe }\end{array}$ & 0.97 & 0.91 & 0.39 & 0.5 & 0.75 & 1.02 & 0.41 & 0.9 & 0.73 & 0.84 & 1.02 \\
\hline \multirow{4}{*}{$\mathrm{RP}$} & $\begin{array}{l}\text { Average } \\
\text { return }\end{array}$ & 5.14 & 4.85 & 4.77 & 4.73 & 4.85 & 4.17 & 5.05 & 4.56 & 5.02 & 4.73 & 3.35 \\
\hline & $\mathrm{SD}$ & 3.21 & 3.2 & 3.13 & 3.16 & 3.16 & 2.61 & 3.11 & 3.18 & 2.88 & 3.08 & 2.55 \\
\hline & Sharpe ratio & 1.6 & 1.52 & 1.52 & 1.49 & 1.53 & 1.6 & 1.62 & 1.44 & 1.74 & 1.53 & 1.31 \\
\hline & $\begin{array}{l}\text { Modified } \\
\text { Sharpe }\end{array}$ & 0.53 & 0.47 & 0.39 & 0.36 & 0.48 & 0.66 & 0.58 & 0.49 & 0.54 & 0.42 & 0.35 \\
\hline \multirow{4}{*}{$\operatorname{maxSR}$} & $\begin{array}{l}\text { Average } \\
\text { return }\end{array}$ & 4.88 & 5.07 & 5.04 & 5.1 & 5.02 & 4.56 & 5.21 & 4.95 & 5.2 & 4.93 & 4.79 \\
\hline & $\mathrm{SD}$ & 3.03 & 2.64 & 2.99 & 2.95 & 2.9 & 2.55 & 2.69 & 2.92 & 2.64 & 2.76 & 2.32 \\
\hline & Sharpe ratio & 1.61 & 1.92 & 1.68 & 1.73 & 1.73 & 1.78 & 1.94 & 1.69 & 1.97 & 1.78 & 2.06 \\
\hline & $\begin{array}{l}\text { Modified } \\
\text { Sharpe }\end{array}$ & 0.38 & 1.01 & 0.74 & 0.42 & 0.71 & 0.8 & 0.9 & 0.84 & 0.88 & 0.89 & 0.82 \\
\hline \multirow{4}{*}{ RRT } & $\begin{array}{l}\text { Average } \\
\text { return }\end{array}$ & 5.07 & 4.83 & 4.91 & 4.95 & 4.86 & 4.91 & 4.83 & 5 & 4.94 & 4.77 & 4.22 \\
\hline & $\mathrm{SD}$ & 5.68 & 5.51 & 5.59 & 5.5 & 5.58 & 5.36 & 5.58 & 5.47 & 5.11 & 5.54 & 4.55 \\
\hline & Sharpe ratio & 0.89 & 0.88 & 0.88 & 0.9 & 0.87 & 0.91 & 0.87 & 0.91 & 0.97 & 0.86 & 0.93 \\
\hline & $\begin{array}{l}\text { Modified } \\
\text { Sharpe }\end{array}$ & 0.23 & 0.22 & 0.22 & 0.22 & 0.22 & 0.24 & 0.22 & 0.26 & 0.25 & 0.21 & 0.23 \\
\hline \multirow{4}{*}{ EW } & $\begin{array}{l}\text { Average } \\
\text { return }\end{array}$ & 7.09 & 6.4 & 6.19 & 6.48 & 6.36 & 6.15 & 6.56 & 6.44 & 6.64 & 6.4 & 4.33 \\
\hline & $\mathrm{SD}$ & 10.34 & 9.4 & 9.79 & 9.38 & 9.61 & 8.86 & 9.52 & 9 & 9.09 & 9.47 & 6.49 \\
\hline & Sharpe ratio & 0.69 & 0.68 & 0.63 & 0.69 & 0.66 & 0.69 & 0.69 & 0.71 & 0.73 & 0.67 & 0.67 \\
\hline & $\begin{array}{l}\text { Modified } \\
\text { Sharpe }\end{array}$ & 0.24 & 0.23 & 0.16 & 0.22 & 0.22 & 0.24 & 0.24 & 0.25 & 0.26 & 0.21 & 0.16 \\
\hline \multirow{4}{*}{ s.w. } & $\begin{array}{l}\text { Average } \\
\text { return }\end{array}$ & 7.29 & 7.1 & 7.03 & 7.13 & 7.09 & 7.02 & 7.16 & 7.12 & 7.19 & 7.1 & 7.1 \\
\hline & $\mathrm{SD}$ & 11.84 & 11.89 & 11.99 & 11.87 & 11.96 & 11.7 & 11.93 & 11.74 & 11.78 & 11.91 & 11.86 \\
\hline & Sharpe ratio & 0.62 & 0.6 & 0.59 & 0.6 & 0.59 & 0.6 & 0.6 & 0.61 & 0.61 & 0.6 & 0.6 \\
\hline & $\begin{array}{l}\text { Modified } \\
\text { Sharpe }\end{array}$ & 0.22 & 0.21 & 0.2 & 0.21 & 0.21 & 0.22 & 0.22 & 0.22 & 0.22 & 0.21 & 0.21 \\
\hline
\end{tabular}


In Exhibit 9, we look at the difference between selected portfolios using unsmoothed returns and ETL as a risk metric and the ones using a naive approach with unadjusted returns and SD as a risk metric. We compare the base portfolio using unsmoothed returns and ETL to the base portfolio using a naive approach and so on. Naturally, there is no difference in the equally weighted and strategically weighted portfolios, given that these have the same weights, regardless of the approach. Further, we observe that, in a majority of cases, we could increase our returns by unsmoothing the HF returns and by using ETL as a risk metric. The largest increase is observed in the case of the relative value portfolio with an minSD allocation, which improves by $1.08 \%$. However, this improvement is associated with its own costs because we increase volatility for all portfolios. However, in most of the cases, we find positive Sharpe and modified Sharpe ratios on the return-risk differential. However, there are only two portfolios with a significant difference in Sharpe ratios, namely, the equity market neutral portfolio with a minRisk allocation and the global hedge fund portfolio with a maxSR allocation. The t-statistics are 2.36 and 2.40, respectively. Hence, we improve only the risk-adjusted performance on roughly $4.5 \%$ of the portfolios (of those we are optimising), on average. Thus, we conclude that unsmoothing the returns and using ETL as a risk metric do not lead to significant improvements over the naive approach using unadjusted returns and SD as a risk metric.

\subsection{Subperiods}

We split our sample into three sub-samples covering the periods 2001-2005, 2006-2010, and 2011-2016, wherein the final sub-sample is one year longer than the other two. The first period covers the dot-com bubble, and the market, as measured by the S\&P500 index, barely recovers the losses at the end of the period. The second sub-sample covers the GFC, with a market crash from October 2007 until February 2009. The final sample covers the Euro crisis that took place in 2011; however, overall, this period is characterised by stable growth. We consider the same HF indices and allocation strategies as in the previous section; for brevity, we put these exhibits in the appendix. First, we examine the use of unadjusted HF

returns and SD as a risk metric, followed by the use of unsmoothed HF returns and ETL as a risk measure. 
Exhibit 9: Difference between the case with the portfolio selection using unsmoothed returns and CornishFisher ES as selection criteria and the case with the selection using unadjusted returns and SD as selection criteria. The superiority of the method using the unsmoothed returns and Cornish-Fischer ETL to the naive approach is indicated in bold.

\begin{tabular}{|c|c|c|c|c|c|c|c|c|c|c|c|c|}
\hline \multirow{3}{*}{$\begin{array}{l}\text { Asset } \\
\text { Allocation } \\
\text { Strategy }\end{array}$} & \multirow{3}{*}{$\begin{array}{l}\text { Performance } \\
\text { Measure }\end{array}$} & \multirow{3}{*}{$\begin{array}{l}\text { Stock- } \\
\text { Bond } \\
\text { Portfolio }\end{array}$} & \multicolumn{10}{|c|}{ Stock-bond portfolio including hedgefunds } \\
\hline & & & Global & Convertible & Distressed & Equity & Equity & Event & Macro & Merger & Relative & All \\
\hline & & & $\begin{array}{l}\text { Hedge- } \\
\text { funds }\end{array}$ & Arb. & & Hedge & $\begin{array}{l}\text { Market } \\
\text { Neutral }\end{array}$ & Driven & Strategy & Arb & Value & \\
\hline \multirow{5}{*}{$\operatorname{minSD}$} & Average & 0.5 & 0.36 & 0.28 & 0.33 & 0.08 & 1 & -0.11 & 0.34 & 0.24 & 1.08 & 0.49 \\
\hline & $\mathrm{SD}$ & 0.98 & 1.19 & 2.08 & 1.5 & 1.21 & 1.54 & 1.34 & 1.06 & 1.37 & 1.59 & 1.35 \\
\hline & Sharpe ratio & 0.51 & 0.3 & 0.13 & 0.22 & 0.06 & 0.65 & -0.08 & 0.32 & 0.18 & 0.68 & 0.36 \\
\hline & Modified & 0.28 & 0.32 & 0.05 & 0.07 & 0.03 & 0.6 & -0.02 & 0.17 & 0.05 & 0.4 & 0.19 \\
\hline & Sharpe & & & & & & & & & & & \\
\hline \multirow{4}{*}{$\mathrm{RP}$} & $\begin{array}{l}\text { Average } \\
\text { return }\end{array}$ & 0.04 & 0.19 & 0.45 & 0.15 & 0.13 & 0.39 & 0.21 & 0 & 0.15 & 0.25 & 0.21 \\
\hline & $\mathrm{SD}$ & 1.17 & 0.82 & 1.72 & 1.06 & 1.06 & 0.76 & 0.96 & 0.97 & 0.99 & 1.21 & 0.82 \\
\hline & Sharpe ratio & 0.03 & 0.22 & 0.26 & 0.14 & 0.12 & 0.51 & 0.22 & 0 & 0.15 & 0.2 & 0.25 \\
\hline & $\begin{array}{l}\text { Modified } \\
\text { Sharpe }\end{array}$ & 0.02 & 0.18 & 0.44 & 0.09 & 0.04 & 0.23 & 0.12 & 0 & 0.06 & 0.16 & 0.24 \\
\hline \multirow{4}{*}{$\operatorname{maxSR}$} & $\begin{array}{l}\text { Average } \\
\text { return }\end{array}$ & 0.12 & 0.94 & 0.54 & 0.44 & 0.76 & 0.52 & 0.26 & 0.69 & 0.51 & 0.75 & 0.69 \\
\hline & $\mathrm{SD}$ & 1.06 & 1.22 & 1.69 & 1.27 & 1.29 & 1.42 & 1.11 & 1.44 & 1.14 & 1.41 & 1.46 \\
\hline & Sharpe ratio & 0.11 & 0.77 & 0.32 & 0.35 & 0.59 & 0.36 & 0.24 & 0.48 & 0.44 & 0.53 & 0.47 \\
\hline & $\begin{array}{l}\text { Modified } \\
\text { Sharpe }\end{array}$ & 0.03 & 0.62 & 0.28 & 0.12 & 0.3 & 0.34 & 0.12 & 0.32 & 0.2 & 0.4 & 0.36 \\
\hline \multirow{4}{*}{ RRT } & $\begin{array}{l}\text { Average } \\
\text { return }\end{array}$ & 0.48 & 0.56 & 0.51 & 0.66 & 0.51 & 0.62 & 0.48 & 0.47 & 0.47 & 0.68 & 0.66 \\
\hline & $\mathrm{SD}$ & 2.9 & 2.66 & 2.71 & 2.76 & 2.71 & 2.88 & 2.68 & 2.74 & 2.66 & 2.76 & 1.99 \\
\hline & Sharpe ratio & 0.16 & 0.21 & 0.19 & 0.24 & 0.19 & 0.22 & 0.18 & 0.17 & 0.18 & 0.24 & 0.33 \\
\hline & $\begin{array}{l}\text { Modified } \\
\text { Sharpe }\end{array}$ & 0.05 & 0.07 & 0.07 & 0.09 & 0.06 & 0.07 & 0.06 & 0.06 & 0.06 & 0.08 & 0.13 \\
\hline
\end{tabular}


Overall, it appears that the sub-period from 2001-2005 has the best performance for HFs. During this period, we could improve the portfolio returns by adding HFs in the portfolio for all allocation strategies. This is contrary to the whole sample wherein the base portfolio has superior returns in four of the six the allocation strategies. Depending on the allocation strategy, we see return improvements in $20 \%-50 \%$ of the individual portfolios. Further, we get a risk reduction, for all allocation strategies, wherein the lowest proportion of portfolios with lower risk than the base portfolio is for maxSR and strategically weighted allocation strategies, at 30\% and 50\%, respectively. The remainder of the allocation strategies has lower risk in $80 \%$ to $100 \%$ of the portfolios. This is also reflected in the risk-adjusted performance wherein all allocation strategies have at least two portfolios with better Sharpe and modified Sharpe ratios. Again, we test the difference in the Sharpe ratios using the method of Opdyke (2007). The portfolio containing all HFs and an equally weighted allocation has a t-statistic of 3.54, and hence this portfolio significantly outperforms the base portfolio. Hence, only 1 out of 60 portfolios significantly outperform the base portfolio. Compared to the first period, the period from 2006-2010 has a lower number of portfolios with a higher return, lower risk, and risk-adjusted performance measures. The exception is the maxSR allocation strategy wherein we have the same number of portfolios with better return characteristics and a higher number of portfolios with lower risk and better risk-adjusted performance measures than the base portfolio. We could improve the returns for all allocation strategies involving optimisation; the improvements range from $0.13 \%$ to $0.94 \%$. We also test the Sharpe ratios in this period. In this case, we find that the merger arbitrage portfolio with a minRisk allocation strategy has a t-statistic of 1.67, and hence outperforms the base portfolio. This is the only portfolio that outperforms the base portfolio in this period. In the last sub-period, from 2011-2016, the base portfolio, in general, has the highest return, with one exception for the merger arbitrage portfolio, where the minRisk and RRT allocation has $0.76 \%$ and $0.10 \%$ higher average returns. We test the Sharpe ratios and find that the merger arbitrage portfolios with both RRT and maxSR allocations have significant t-statistics, 2.99 and 1.95, respectively.

Using unsmoothed returns and ETL as a performance measure does not have an effect, compared to the naive approach, when it comes to the proportion of significantly different Sharpe ratios. In the first sub-period, the equally weighted portfolio containing all HFs has a t-statistic of 3.54. In the second sub-period, we do not find any significance at all. Finally, in the last sub-period, we find four portfolios. The use of minRisk allocation leads the relative value, merger arbitrage, and the portfolio containing all HFs to obtain significant t-statistics of 2.69, 1.66, and 1.92, respectively. Additionally, the merger arbitrage portfolio using an RRT allocation has a significant t-statistic of 2.14. Hence, we can conclude that our results are not dependent on sub-periods, given that only a few portfolios within each sub-period outperform the base portfolio.

\subsection{Robustness tests}

In addition to assessing a 36-month lookback period with biannual rebalancing, we consider 12- and 24-month lookback periods to test the robustness of our results. Further, we also tested the three mentioned lookback periods with annual rebalancing. In general, the 
results for different lookback periods and rebalancing periods are similar to our base case of the 36-month lookback period and biannual rebalancing.

\section{Conclusion}

The topic on the features that HF have in a portfolio is of interest to both academics and practitioners. We contribute to the literature by making a comprehensive investigation of data from 1998 to 2016 on the effect of the inclusion of HFs in a portfolio on risk-adjusted performance. The results show no significant increase in performance when we compare a broad, well-diversified, portfolio as a benchmark, regardless of the allocation strategy and types of HF considered in our study. Additionally, the use of an ETL risk metric, which accounts for the higher moments in the hedge fund distribution and unsmoothing of the HF returns, does not, on average, prove superior to the use of an SD as a risk metric on the unadjusted HF returns. Consequently, from an investor perspective, it seems unnecessary to examine this aspect of the investment universe to optimise performance. This study indicates that satisfactory performance is achieved based on normal diversification in stocks and bonds, similar to the majority of mutual funds.

\section{References}

Ang, A., Hodrick, R.J., Xing, Y., Zhang, X., 2006. The Cross-Section of Volatility and Expected Returns. The Journal of Finance 61 (1), 259-299. doi:10.1111/j.1540-6261. $2006.00836 . x$.

Ardia, D., Boudt, K.M.R., Carl, P., Mullen, K., Peterson, B., 2011. Differential evolution (DEoptim) for non-convex portfolio optimization. The R Journal 3 (1), 27-34.

Artzner, P., Delbaen, F., Eber, J.M., Heath, D., 1999. Coherent Measures of Risk. Mathematical Finance 9 (3), 203-228. doi:10.1111/1467-9965.00068.

Basak, S., Pavlova, A., 2016. A Model of Financialization of Commodities. The Journal of Finance 71 (4), 1511-1556. doi:10.1111/jofi.12408.

Bessler, W., Wolff, D., 2015. Do commodities add value in multi-asset portfolios? An outof-sample analysis for different investment strategies. Journal of Banking $\&$ Finance 60, 1-20. doi:10.1016/J . JBANKFIN . 2015.06.021.

Best, M.J., Grauer, R.R., 1991. On the Sensitivity of Mean-Variance-Efficient Portfolios to Changes in Asset Means: Some Analytical and Computational Results. Review of Financial Studies 4 (2), 315-342. doi:10.1093/rfs/4.2.315.

Bhardwaj, G., Gorton, G.B., Rouwenhorst, K.G., 2016. Investor Interest and the Returns to Commodity Investing. The Journal of Portfolio Management 42 (3), 44-55. doi:10. 3905/jpm. 2016.42.3.044. 
Blitz, D.C., van Vliet, P., 2007. The Volatility Effect. The Journal of Portfolio Management 34 (1), 102-113. doi:10.3905/jpm.2007.698039.

Booth, D.G., Fama, E.F., 1992. Diversification Returns and Asset Contributions. Financial Analysts Journal 48 (3), 26-32. doi:10.2469/faj.v48.n3.26.

Boudt, K., Peterson, B.G., Croux, C., 2008. Estimation and Decomposition of Downside Risk for Portfolios with Non-Normal Returns. Journal of Risk 11 (2), 79-103. doi:10. $2139 /$ ssrn. 1024151.

Brooks, C., Kat, H.M., 2002. The Statistical Properties of Hedge Fund Index Returns and Their Implications for Investors. The Journal of Alternative Investments 5 (2), 26-44. doi:10.3905/jai.2002.319053.

Brown, S.J., 2016. Why Hedge Funds? Financial Analysts Journal 72 (6), 5-7. doi:10. 2469/faj.v72.n6.6.

Brown, S.J., Gregoriou, G.N., Pascalau, R., 2012. Diversification in Funds of Hedge Funds: Is It Possible to Overdiversify? Review of Asset Pricing Studies 2 (1), 89-110. doi:10. 1093/rapstu/rar003.

Cavenaile, L., Coën, A., Hübner, G., 2011. The Impact of Illiquidity and Higher Moments ofHedge Fund Returns on Their Risk-AdjustedPerformance and Diversification Potential. The Journal of Alternative Investments 13 (4), 9-29. doi:10.3905/jai.2011.13.4.009.

Chopra, V.K., Ziemba, W.T., 2011. The Kelly Capital Growth Investment Criterion, in: MacLean, L.C., Thorp, E.O., Ziemba, W.T. (Eds.), The Kelly Capital Growth Investment Criterion: Theory and Practice. World Scientific. volume 3 of World Scientific Handbook in Financial Economics Series. chapter 18, pp. 249-257. doi:10.1142/7598.

Cvitanic, J., Lazrak, A., Martellini, L., Zapatero, F., 2003. Optimal allocation to hedge funds: an empirical analysis. Quantitative Finance 3 (1), 28-39. doi:10.1088/1469$7688 / 3 / 1 / 303$.

Davies, R.J., Kat, H.M., Lu, S., 2009. Fund of hedge funds portfolio selection: A multipleobjective approach. Journal of Derivatives \& Hedge Funds 15 (2), 91-115. doi:10.1057/ jdhf.2009.1.

DeMiguel, V., Garlappi, L., Uppal, R., 2009. Optimal Versus Naive Diversification: How Inefficient is the 1/ N Portfolio Strategy? Review of Financial Studies 22 (5), 1915-1953. doi:10.1093/rfs/hhm075.

Denvir, E., Hutson, E., 2006. The performance and diversification benefits of funds of hedge funds. Journal of International Financial Markets, Institutions and Money 16 (1), 4-22. doi:10.1016/J . INTFIN . 2004.12.002. 
Eling, M., Schuhmacher, F., 2007. Does the choice of performance measure influence the evaluation of hedge funds? Journal of Banking $\&$ Finance 31 (9), 2632-2647. doi:10. 1016/J . JBANKFIN . 2006.09.015.

Erb, C.B., Harvey, C.R., 2006. The Strategic and Tactical Value of Commodity Futures. Financial Analysts Journal 62 (2), 69-97. doi:10.2469/faj.v62.n2.4084.

Frydenberg, S., Hrafnkelsson, K., Bromseth, V.S., Westgaard, S., 2017. Hedge Fund Strategies and Time-Varying Alphas and Betas. The Journal of Wealth Management 19 (4), 44-60. doi:10.3905/jwm.2017.19.4.044.

Gallais-Hamonno, G., Nguyen-Thi-Thanh, H., 2008. La nécessité de corriger les rentabilités des hedge funds, preuve empirique et méthode de correction. Banque et Marchés 96, 6-19.

Getmansky, M., Lo, A.W., Makarov, I., 2004. An econometric model of serial correlation and illiquidity in hedge fund returns. Journal of Financial Economics 74 (3), 529-609. doi:10.1016/J . JFINECO . 2004.04.001.

Haglund, M., 2010. Higher moment diversification benefits of hedge fund strategy allocation. Journal of Derivatives \& Hedge Funds 16 (1), 53-69. doi:10.1057/jdhf.2010.2.

Inker, B., 2011. The Dangers of Risk Parity. The Journal of Investing 20 (1), 90-98. doi:10.3905/joi.2011.20.1.090.

Irwin, S.H., Sanders, D.R., 2011. Index Funds, Financialization, and Commodity Futures Markets. Applied Economic Perspectives and Policy 33 (1), 1-31. doi:10.1093/aepp/ ppq032.

Jordan, B.D., Riley, T.B., 2015. Volatility and mutual fund manager skill. Journal of Financial Economics 118 (2), 289-298. doi:10.1016/J . JFINECO.2015.06.012.

Kirby, C., Ostdiek, B., 2012. It's All in the Timing: Simple Active Portfolio Strategies that Outperform Naïve Diversification. Journal of Financial and Quantitative Analysis 47 (02), 437-467. doi:10.1017/S0022109012000117.

Maillard, S., Roncalli, T., Teïletche, J., 2010. The Properties of Equally Weighted Risk Contribution Portfolios. The Journal of Portfolio Management 36 (4), 60-70. doi:10. 3905/jpm.2010.36.4.060.

Norges Bank Investment Management, 2015. The diversification potential of real estate. Discussion note 1/2015. Norges Bank Investment Management.

Opdyke, J.D., 2007. Comparing Sharpe ratios: so where are the p-values? Journal of Asset Management 8 (5), 308-336.

Peterson, B.G., Carl, P., 2018a. PerformanceAnalytics: Econometric Tools for Performance and Risk Analysis. URL: https://cran.r-project.org/package= PerformanceAnalytics. 
Peterson, B.G., Carl, P., 2018b. PortfolioAnalytics: Portfolio Analysis, Including Numerical Methods for Optimization of Portfolios. URL: https://cran.r-project.org/package= PortfolioAnalytics.

Pflug, G.C., Pichler, A., Wozabal, D., 2012. The 1/N investment strategy is optimal under high model ambiguity. Journal of Banking \& Finance 36 (2), 410-417. doi:10.1016/J . JBANKFIN . 2011.07.018.

Qian, E., 2005. Risk parity portfolios: Efficient portfolios through true diversification. Panagora Asset Management.

Roncalli, T., 2013. Introduction to risk parity and budgeting. New York: Chapman and Hall/CRC.

Shawky, H.A., Dai, N., Cumming, D., 2012. Diversification in the hedge fund industry. Journal of Corporate Finance 18 (1), 166-178. doi:10.1016/J. JCORPFIN. 2011.11.006.

Stoyanov, S.V., Rachev, S.T., Fabozzi, F.J., 2007. Optimal Financial Portfolios. Applied Mathematical Finance 14 (5), 401-436. doi:10.1080/13504860701255292.

Viceira, L.M., Wang, Z.K., Zhou, J., 2017. Global Portfolio Diversification for Long-Horizon Investors. Working Paper. Harvard Business School, doi:10.2139/ssrn. 2941652.

\section{Appendix}

Exhibits on sub-samples using both unadjusted returns and SD as the risk metric, in addition to unsmoothed returns and ETL as the risk metric. 
Exhibit 10: Subperiod 2001-2005: Using unadjusted returns and SD as a risk metric.

\begin{tabular}{|c|c|c|c|c|c|c|c|c|c|c|c|c|}
\hline \multirow[b]{2}{*}{$\begin{array}{l}\text { Asset } \\
\text { Allocation } \\
\text { Strategy }\end{array}$} & \multirow[b]{2}{*}{$\begin{array}{l}\text { Performance } \\
\text { Measure }\end{array}$} & \multirow[b]{2}{*}{$\begin{array}{l}\text { Stock- } \\
\text { Bond } \\
\text { Portfolio }\end{array}$} & \multicolumn{10}{|c|}{ Stock-bond portfolio including hedgefunds } \\
\hline & & & $\begin{array}{l}\text { Global } \\
\text { Hedge- } \\
\text { funds }\end{array}$ & $\begin{array}{l}\text { Convertible } \\
\text { Arb. }\end{array}$ & Distressed & $\begin{array}{l}\text { Equity } \\
\text { Hedge }\end{array}$ & $\begin{array}{l}\text { Equity } \\
\text { Market } \\
\text { Neutral }\end{array}$ & $\begin{array}{l}\text { Event } \\
\text { Driven }\end{array}$ & $\begin{array}{l}\text { Macro } \\
\text { Strategy }\end{array}$ & $\begin{array}{l}\text { Merger } \\
\text { Arb }\end{array}$ & $\begin{array}{l}\text { Relative } \\
\text { Value }\end{array}$ & All \\
\hline \multirow{4}{*}{ minRisk } & $\begin{array}{l}\text { Average } \\
\text { return }\end{array}$ & 5.46 & 5.58 & 5.98 & 6.25 & 5.62 & 4.93 & 5.79 & 5.44 & 4.35 & 4.16 & 4.83 \\
\hline & $\mathrm{SD}$ & 2.7 & 2.55 & 2.89 & 2.71 & 2.57 & 2.4 & 2.67 & 2.67 & 2.33 & 2.38 & 2.32 \\
\hline & Sharpe ratio & 2.02 & 2.19 & 2.07 & 2.3 & 2.19 & 2.05 & 2.17 & 2.04 & 1.87 & 1.75 & 2.08 \\
\hline & $\begin{array}{l}\text { Modified } \\
\text { Sharpe }\end{array}$ & 1.09 & 1.12 & 1.2 & 1.24 & 1.32 & 1.05 & 1.21 & 1.07 & 0.91 & 0.95 & 1.22 \\
\hline \multirow{4}{*}{$\mathrm{RP}$} & $\begin{array}{l}\text { Average } \\
\text { return }\end{array}$ & 6.16 & 6 & 6.18 & 6.8 & 6.01 & 4.78 & 6.06 & 6.25 & 5.48 & 5.69 & 5.12 \\
\hline & $\mathrm{SD}$ & 3 & 2.87 & 2.77 & 2.93 & 2.87 & 2.4 & 2.92 & 3.02 & 2.8 & 2.52 & 2.31 \\
\hline & Sharpe ratio & 2.05 & 2.09 & 2.23 & 2.32 & 2.09 & 1.99 & 2.07 & 2.07 & 1.96 & 2.25 & 2.22 \\
\hline & $\begin{array}{l}\text { Modified } \\
\text { Sharpe }\end{array}$ & 1.24 & 1.28 & 1.33 & 1.45 & 1.29 & 1 & 1.28 & 1.18 & 1.14 & 1.34 & 1.3 \\
\hline \multirow{4}{*}{$\operatorname{maxSR}$} & $\begin{array}{l}\text { Average } \\
\text { return }\end{array}$ & 5.59 & 5.25 & 5.97 & 6.34 & 5.57 & 5.46 & 5.75 & 5.17 & 5.47 & 4.7 & 4.49 \\
\hline & $\mathrm{SD}$ & 2.51 & 2.47 & 3.23 & 2.74 & 2.69 & 2.52 & 2.52 & 2.81 & 2.58 & 2.2 & 2.47 \\
\hline & Sharpe ratio & 2.22 & 2.13 & 1.85 & 2.31 & 2.07 & 2.16 & 2.28 & 1.84 & 2.12 & 2.14 & 1.82 \\
\hline & $\begin{array}{l}\text { Modified } \\
\text { Sharpe }\end{array}$ & 1.14 & 1 & 1.02 & 1.41 & 1.09 & 1.14 & 1.26 & 0.81 & 1.15 & 1.19 & 1.01 \\
\hline \multirow{4}{*}{ RRT } & $\begin{array}{l}\text { Average } \\
\text { return }\end{array}$ & 5.92 & 5.66 & 6.22 & 6.35 & 5.75 & 5.5 & 5.75 & 5.91 & 5.17 & 5.22 & 5.42 \\
\hline & SD & 2.66 & 2.47 & 2.61 & 2.54 & 2.49 & 2.56 & 2.51 & 2.68 & 2.49 & 2.1 & 2.32 \\
\hline & Sharpe ratio & 2.22 & 2.29 & 2.39 & 2.49 & 2.31 & 2.14 & 2.29 & 2.2 & 2.07 & 2.49 & 2.34 \\
\hline & $\begin{array}{l}\text { Modified } \\
\text { Sharpe }\end{array}$ & 1.17 & 1.29 & 1.29 & 1.4 & 1.33 & 1.09 & 1.24 & 1.13 & 1.04 & 1.36 & 1.43 \\
\hline \multirow{4}{*}{ EW } & $\begin{array}{l}\text { Average } \\
\text { return }\end{array}$ & 7.78 & 7.56 & 7.44 & 8.34 & 7.55 & 6.85 & 7.57 & 7.87 & 7.05 & 7.42 & 6.71 \\
\hline & SD & 8.45 & 7.5 & 7.35 & 7.62 & 7.64 & 7.14 & 7.83 & 7.42 & 7.54 & 7.35 & 4.69 \\
\hline & Sharpe ratio & 0.92 & 1.01 & 1.01 & 1.09 & 0.99 & 0.96 & 0.97 & 1.06 & 0.94 & 1.01 & 1.43 \\
\hline & $\begin{array}{l}\text { Modified } \\
\text { Sharpe }\end{array}$ & 0.44 & 0.5 & 0.5 & 0.53 & 0.49 & 0.46 & 0.47 & 0.54 & 0.45 & 0.5 & 0.76 \\
\hline \multirow{4}{*}{ s.w. } & $\begin{array}{l}\text { Average } \\
\text { return }\end{array}$ & 7.92 & 7.87 & 7.83 & 8.15 & 7.87 & 7.62 & 7.88 & 7.98 & 7.69 & 7.83 & 7.86 \\
\hline & $\mathrm{SD}$ & 9.79 & 9.79 & 9.73 & 9.82 & 9.84 & 9.66 & 9.91 & 9.75 & 9.8 & 9.74 & 9.78 \\
\hline & Sharpe ratio & 0.81 & 0.8 & 0.8 & 0.83 & 0.8 & 0.79 & 0.79 & 0.82 & 0.78 & 0.8 & 0.8 \\
\hline & $\begin{array}{l}\text { Modified } \\
\text { Sharpe }\end{array}$ & 0.38 & 0.38 & 0.38 & 0.39 & 0.38 & 0.37 & 0.38 & 0.39 & 0.37 & 0.38 & 0.38 \\
\hline
\end{tabular}


Exhibit 11: Subperiod 2006-2010: Using unadjusted returns and SD as a risk metric.

\begin{tabular}{|c|c|c|c|c|c|c|c|c|c|c|c|c|}
\hline \multirow[b]{2}{*}{$\begin{array}{l}\text { Asset } \\
\text { Allocation } \\
\text { Strategy }\end{array}$} & \multirow[b]{2}{*}{$\begin{array}{l}\text { Performance } \\
\text { Measure }\end{array}$} & \multirow[b]{2}{*}{$\begin{array}{l}\text { Stock- } \\
\text { Bond } \\
\text { Portfolio }\end{array}$} & \multicolumn{10}{|c|}{ Stock-bond portfolio including hedgefunds } \\
\hline & & & $\begin{array}{l}\text { Global } \\
\text { Hedge- } \\
\text { funds }\end{array}$ & $\begin{array}{l}\text { Convertible } \\
\text { Arb. }\end{array}$ & Distressed & $\begin{array}{l}\text { Equity } \\
\text { Hedge }\end{array}$ & $\begin{array}{l}\text { Equity } \\
\text { Market } \\
\text { Neutral }\end{array}$ & $\begin{array}{l}\text { Event } \\
\text { Driven }\end{array}$ & $\begin{array}{l}\text { Macro } \\
\text { Strategy }\end{array}$ & $\begin{array}{l}\text { Merger } \\
\text { Arb }\end{array}$ & $\begin{array}{l}\text { Relative } \\
\text { Value }\end{array}$ & All \\
\hline \multirow{4}{*}{ minRisk } & $\begin{array}{l}\text { Average } \\
\text { return }\end{array}$ & 4.91 & 4.26 & 4.08 & 3.69 & 5.17 & 3.05 & 5.14 & 4.64 & 5.26 & 4.83 & 4.58 \\
\hline & $\mathrm{SD}$ & 3.08 & 3.39 & 3 & 2.94 & 3.22 & 2.52 & 2.87 & 2.94 & 2.63 & 3.15 & 2.15 \\
\hline & Sharpe ratio & 1.59 & 1.26 & 1.36 & 1.25 & 1.6 & 1.21 & 1.79 & 1.58 & 2 & 1.53 & 2.13 \\
\hline & $\begin{array}{l}\text { Modified } \\
\text { Sharpe }\end{array}$ & 0.59 & 0.39 & 0.47 & 0.36 & 0.67 & 0.39 & 0.88 & 0.75 & 1.3 & 0.58 & 0.95 \\
\hline \multirow{4}{*}{$\mathrm{RP}$} & $\begin{array}{l}\text { Average } \\
\text { return }\end{array}$ & 5.51 & 5.04 & 3.52 & 3.87 & 5.17 & 3.98 & 5.2 & 4.89 & 5.64 & 4.78 & 2.65 \\
\hline & $\mathrm{SD}$ & 5.24 & 4.87 & 6.31 & 4.79 & 4.97 & 3.39 & 4.82 & 4.7 & 4.47 & 5.24 & 3.82 \\
\hline & Sharpe ratio & 1.05 & 1.04 & 0.56 & 0.81 & 1.04 & 1.18 & 1.08 & 1.04 & 1.26 & 0.91 & 0.69 \\
\hline & $\begin{array}{l}\text { Modified } \\
\text { Sharpe }\end{array}$ & 0.31 & 0.3 & 0.13 & 0.2 & 0.31 & 0.37 & 0.32 & 0.31 & 0.38 & 0.25 & 0.17 \\
\hline \multirow{4}{*}{$\operatorname{maxSR}$} & $\begin{array}{l}\text { Average } \\
\text { return }\end{array}$ & 5.26 & 4.74 & 5.84 & 4.76 & 5.28 & 4.64 & 6.2 & 4.83 & 5.22 & 5.02 & 5.18 \\
\hline & $\mathrm{SD}$ & 3.61 & 3.3 & 3.37 & 3.06 & 3.03 & 2.61 & 3.24 & 3.94 & 3.36 & 3.64 & 2.4 \\
\hline & Sharpe ratio & 1.45 & 1.43 & 1.73 & 1.56 & 1.74 & 1.77 & 1.91 & 1.22 & 1.55 & 1.38 & 2.16 \\
\hline & $\begin{array}{l}\text { Modified } \\
\text { Sharpe }\end{array}$ & 0.48 & 0.54 & 0.68 & 0.41 & 0.82 & 0.99 & 1.02 & 0.4 & 0.68 & 0.37 & 1.19 \\
\hline \multirow{4}{*}{ RRT } & $\begin{array}{l}\text { Average } \\
\text { return }\end{array}$ & 4.56 & 4.01 & 4.01 & 3.31 & 4.18 & 4.32 & 4.21 & 4.42 & 4.79 & 3.82 & 2.62 \\
\hline & $\mathrm{SD}$ & 4.73 & 4.79 & 5.03 & 4.65 & 4.82 & 4.23 & 4.76 & 4.65 & 4.2 & 4.78 & 4.44 \\
\hline & Sharpe ratio & 0.96 & 0.84 & 0.8 & 0.71 & 0.87 & 1.02 & 0.88 & 0.95 & 1.14 & 0.8 & 0.59 \\
\hline & $\begin{array}{l}\text { Modified } \\
\text { Sharpe }\end{array}$ & 0.26 & 0.22 & 0.2 & 0.17 & 0.23 & 0.29 & 0.24 & 0.27 & 0.33 & 0.2 & 0.15 \\
\hline \multirow{4}{*}{ EW } & $\begin{array}{l}\text { Average } \\
\text { return }\end{array}$ & 7.51 & 6.6 & 5.75 & 5.89 & 6.6 & 6.55 & 6.68 & 6.59 & 7.36 & 6.77 & 3.56 \\
\hline & $\mathrm{SD}$ & 13.98 & 12.77 & 13.9 & 12.54 & 13.02 & 11.93 & 12.75 & 12.17 & 12.22 & 13.09 & 9.14 \\
\hline & Sharpe ratio & 0.54 & 0.52 & 0.41 & 0.47 & 0.51 & 0.55 & 0.52 & 0.54 & 0.6 & 0.52 & 0.39 \\
\hline & $\begin{array}{l}\text { Modified } \\
\text { Sharpe }\end{array}$ & 0.2 & 0.19 & 0.12 & 0.16 & 0.19 & 0.21 & 0.19 & 0.21 & 0.23 & 0.18 & 0.11 \\
\hline \multirow{4}{*}{ s.w. } & $\begin{array}{l}\text { Average } \\
\text { return }\end{array}$ & 7.61 & 7.32 & 7.02 & 7.07 & 7.32 & 7.3 & 7.34 & 7.31 & 7.58 & 7.38 & 7.29 \\
\hline & $\mathrm{SD}$ & 15.92 & 15.98 & 16.32 & 15.89 & 16.06 & 15.69 & 15.97 & 15.76 & 15.79 & 16.07 & 15.94 \\
\hline & Sharpe ratio & 0.48 & 0.46 & 0.43 & 0.44 & 0.46 & 0.47 & 0.46 & 0.46 & 0.48 & 0.46 & 0.46 \\
\hline & $\begin{array}{l}\text { Modified } \\
\text { Sharpe }\end{array}$ & 0.19 & 0.18 & 0.16 & 0.17 & 0.18 & 0.18 & 0.18 & 0.18 & 0.19 & 0.18 & 0.18 \\
\hline
\end{tabular}


Exhibit 12: Subperiod 2011-2016: Using unadjusted returns and SD as a risk metric.

\begin{tabular}{|c|c|c|c|c|c|c|c|c|c|c|c|c|}
\hline \multirow[b]{2}{*}{$\begin{array}{l}\text { Asset } \\
\text { Allocation } \\
\text { Strategy }\end{array}$} & \multirow[b]{2}{*}{$\begin{array}{l}\text { Performance } \\
\text { Measure }\end{array}$} & \multirow[b]{2}{*}{$\begin{array}{l}\text { Stock- } \\
\text { Bond } \\
\text { Portfolio }\end{array}$} & \multicolumn{10}{|c|}{ Stock-bond portfolio including hedgefunds } \\
\hline & & & $\begin{array}{l}\text { Global } \\
\text { Hedge- } \\
\text { funds }\end{array}$ & $\begin{array}{l}\text { Convertible } \\
\text { Arb. }\end{array}$ & Distressed & $\begin{array}{l}\text { Equity } \\
\text { Hedge }\end{array}$ & $\begin{array}{l}\text { Equity } \\
\text { Market } \\
\text { Neutral }\end{array}$ & $\begin{array}{l}\text { Event } \\
\text { Driven }\end{array}$ & $\begin{array}{l}\text { Macro } \\
\text { Strategy }\end{array}$ & $\begin{array}{l}\text { Merger } \\
\text { Arb }\end{array}$ & $\begin{array}{l}\text { Relative } \\
\text { Value }\end{array}$ & All \\
\hline \multirow{4}{*}{ minRisk } & $\begin{array}{l}\text { Average } \\
\text { return }\end{array}$ & 3.17 & 2.76 & 2.67 & 2.85 & 2.93 & 2.36 & 3.05 & 3.11 & 3.93 & 2.41 & 2.83 \\
\hline & $\mathrm{SD}$ & 2.19 & 2.13 & 2.38 & 2.18 & 2.13 & 2.06 & 2.16 & 2.14 & 2.08 & 2.05 & 1.9 \\
\hline & Sharpe ratio & 1.44 & 1.29 & 1.12 & 1.31 & 1.38 & 1.15 & 1.41 & 1.46 & 1.88 & 1.17 & 1.49 \\
\hline & $\begin{array}{l}\text { Modified } \\
\text { Sharpe }\end{array}$ & 0.73 & 0.68 & 0.51 & 0.71 & 0.7 & 0.58 & 0.78 & 0.78 & 0.89 & 0.61 & 0.75 \\
\hline \multirow{4}{*}{$\mathrm{RP}$} & $\begin{array}{l}\text { Average } \\
\text { return }\end{array}$ & 3.86 & 3.25 & 3.42 & 3.32 & 3.28 & 2.78 & 3.53 & 2.89 & 3.7 & 3.22 & 1.91 \\
\hline & $\mathrm{SD}$ & 2.74 & 2.61 & 2.45 & 2.78 & 2.69 & 2.3 & 2.7 & 2.59 & 2.22 & 2.55 & 2.05 \\
\hline & Sharpe ratio & 1.41 & 1.24 & 1.4 & 1.19 & 1.22 & 1.21 & 1.31 & 1.11 & 1.67 & 1.26 & 0.93 \\
\hline & $\begin{array}{l}\text { Modified } \\
\text { Sharpe }\end{array}$ & 0.77 & 0.67 & 0.8 & 0.65 & 0.65 & 0.62 & 0.72 & 0.56 & 0.9 & 0.71 & 0.42 \\
\hline \multirow{4}{*}{$\operatorname{maxSR}$} & $\begin{array}{l}\text { Average } \\
\text { return }\end{array}$ & 3.66 & 2.69 & 2.16 & 3.17 & 2.33 & 2.35 & 3.24 & 3.03 & 3.6 & 3.03 & 2.87 \\
\hline & $\mathrm{SD}$ & 2.37 & 2.29 & 2.44 & 2.39 & 2.26 & 2.34 & 2.35 & 2.27 & 2.05 & 2.44 & 2.01 \\
\hline & Sharpe ratio & 1.55 & 1.17 & 0.88 & 1.32 & 1.03 & 1 & 1.38 & 1.34 & 1.75 & 1.24 & 1.43 \\
\hline & $\begin{array}{l}\text { Modified } \\
\text { Sharpe }\end{array}$ & 0.83 & 0.61 & 0.43 & 0.69 & 0.53 & 0.53 & 0.7 & 0.66 & 1.03 & 0.66 & 0.7 \\
\hline \multirow{4}{*}{ RRT } & $\begin{array}{l}\text { Average } \\
\text { return }\end{array}$ & 3.52 & 3.33 & 3.21 & 3.38 & 3.31 & 3.24 & 3.31 & 3.48 & 3.62 & 3.39 & 2.79 \\
\hline & $\mathrm{SD}$ & 2.87 & 2.84 & 2.74 & 2.87 & 2.89 & 2.59 & 2.91 & 2.83 & 2.21 & 2.82 & 2.14 \\
\hline & Sharpe ratio & 1.23 & 1.17 & 1.17 & 1.18 & 1.15 & 1.25 & 1.14 & 1.23 & 1.64 & 1.2 & 1.31 \\
\hline & $\begin{array}{l}\text { Modified } \\
\text { Sharpe }\end{array}$ & 0.52 & 0.51 & 0.5 & 0.51 & 0.48 & 0.58 & 0.49 & 0.52 & 0.87 & 0.53 & 0.71 \\
\hline \multirow{4}{*}{ EW } & $\begin{array}{l}\text { Average } \\
\text { return }\end{array}$ & 6.17 & 5.27 & 5.52 & 5.42 & 5.15 & 5.24 & 5.62 & 5.11 & 5.7 & 5.22 & 3 \\
\hline & $\mathrm{SD}$ & 8.12 & 7.42 & 7.23 & 7.59 & 7.66 & 7.09 & 7.59 & 7 & 7.12 & 7.35 & 5.02 \\
\hline & Sharpe ratio & 0.76 & 0.71 & 0.76 & 0.71 & 0.67 & 0.74 & 0.74 & 0.73 & 0.8 & 0.71 & 0.6 \\
\hline & $\begin{array}{l}\text { Modified } \\
\text { Sharpe }\end{array}$ & 0.32 & 0.3 & 0.33 & 0.3 & 0.28 & 0.3 & 0.32 & 0.3 & 0.33 & 0.3 & 0.25 \\
\hline \multirow{4}{*}{ s.w. } & $\begin{array}{l}\text { Average } \\
\text { return }\end{array}$ & 6.51 & 6.28 & 6.37 & 6.34 & 6.24 & 6.27 & 6.41 & 6.23 & 6.43 & 6.27 & 6.32 \\
\hline & $\mathrm{SD}$ & 9.33 & 9.39 & 9.32 & 9.44 & 9.47 & 9.28 & 9.45 & 9.24 & 9.29 & 9.37 & 9.35 \\
\hline & Sharpe ratio & 0.7 & 0.67 & 0.68 & 0.67 & 0.66 & 0.68 & 0.68 & 0.67 & 0.69 & 0.67 & 0.68 \\
\hline & $\begin{array}{l}\text { Modified } \\
\text { Sharpe }\end{array}$ & 0.29 & 0.28 & 0.28 & 0.28 & 0.27 & 0.28 & 0.28 & 0.28 & 0.28 & 0.28 & 0.28 \\
\hline
\end{tabular}


Exhibit 13: Subperiod 2001-2005: Using unsmoothed returns and ETL as a risk metric.

\begin{tabular}{|c|c|c|c|c|c|c|c|c|c|c|c|c|}
\hline \multirow[b]{2}{*}{$\begin{array}{l}\text { Asset } \\
\text { Allocation } \\
\text { Strategy }\end{array}$} & \multirow[b]{2}{*}{$\begin{array}{l}\text { Performance } \\
\text { Measure }\end{array}$} & \multirow[b]{2}{*}{$\begin{array}{l}\text { Stock- } \\
\text { Bond } \\
\text { Portfolio }\end{array}$} & \multicolumn{10}{|c|}{ Stock-bond portfolio including hedgefunds } \\
\hline & & & $\begin{array}{l}\text { Global } \\
\text { Hedge- } \\
\text { funds }\end{array}$ & $\begin{array}{l}\text { Convertible } \\
\text { Arb. }\end{array}$ & Distressed & $\begin{array}{l}\text { Equity } \\
\text { Hedge }\end{array}$ & $\begin{array}{l}\text { Equity } \\
\text { Market } \\
\text { Neutral }\end{array}$ & $\begin{array}{l}\text { Event } \\
\text { Driven }\end{array}$ & $\begin{array}{l}\text { Macro } \\
\text { Strategy }\end{array}$ & $\begin{array}{l}\text { Merger } \\
\text { Arb }\end{array}$ & $\begin{array}{l}\text { Relative } \\
\text { Value }\end{array}$ & All \\
\hline \multirow{4}{*}{$\operatorname{minSD}$} & $\begin{array}{l}\text { Average } \\
\text { return }\end{array}$ & 6.46 & 5.51 & 6.55 & 6.57 & 5.77 & 6.16 & 5.96 & 6.41 & 5.64 & 5.87 & 5.02 \\
\hline & $\mathrm{SD}$ & 2.62 & 2.53 & 2.78 & 2.64 & 2.66 & 2.58 & 2.55 & 2.72 & 2.55 & 2.48 & 2.24 \\
\hline & Sharpe ratio & 2.47 & 2.18 & 2.35 & 2.49 & 2.16 & 2.39 & 2.34 & 2.36 & 2.21 & 2.36 & 2.24 \\
\hline & $\begin{array}{l}\text { Modified } \\
\text { Sharpe }\end{array}$ & 1.39 & 1.12 & 1.31 & 1.41 & 1.26 & 1.29 & 1.13 & 1.32 & 1.04 & 1.41 & 1.05 \\
\hline \multirow{4}{*}{$\mathrm{RP}$} & $\begin{array}{l}\text { Average } \\
\text { return }\end{array}$ & 6.25 & 5.99 & 6.12 & 6.48 & 6.06 & 5.58 & 6.1 & 6.21 & 5.86 & 5.96 & 4.99 \\
\hline & $\mathrm{SD}$ & 2.79 & 2.68 & 2.63 & 2.67 & 2.71 & 2.46 & 2.66 & 2.88 & 2.61 & 2.45 & 2.38 \\
\hline & Sharpe ratio & 2.24 & 2.23 & 2.33 & 2.43 & 2.24 & 2.27 & 2.3 & 2.16 & 2.25 & 2.44 & 2.1 \\
\hline & $\begin{array}{l}\text { Modified } \\
\text { Sharpe }\end{array}$ & 1.29 & 1.33 & 1.32 & 1.39 & 1.33 & 1.14 & 1.33 & 1.13 & 1.22 & 1.35 & 1.07 \\
\hline \multirow{4}{*}{$\operatorname{maxSR}$} & $\begin{array}{l}\text { Average } \\
\text { return }\end{array}$ & 6.25 & 5.39 & 6.41 & 6.75 & 6.14 & 5.96 & 6.64 & 6.61 & 6.09 & 6.47 & 5.88 \\
\hline & $\mathrm{SD}$ & 2.81 & 2.5 & 2.9 & 2.62 & 2.86 & 2.57 & 2.61 & 2.99 & 2.54 & 2.62 & 2.64 \\
\hline & Sharpe ratio & 2.22 & 2.16 & 2.21 & 2.58 & 2.15 & 2.32 & 2.54 & 2.21 & 2.39 & 2.47 & 2.22 \\
\hline & $\begin{array}{l}\text { Modified } \\
\text { Sharpe }\end{array}$ & 1.2 & 1.14 & 1.28 & 1.36 & 1.28 & 1.18 & 1.39 & 1.1 & 1.2 & 1.35 & 0.96 \\
\hline \multirow{4}{*}{ RRT } & $\begin{array}{l}\text { Average } \\
\text { return }\end{array}$ & 6.61 & 6.32 & 6.66 & 6.85 & 6.31 & 6.24 & 6.37 & 6.5 & 6.06 & 6.09 & 5.84 \\
\hline & $\mathrm{SD}$ & 3.26 & 2.95 & 3.1 & 3.08 & 3.06 & 3.15 & 3.18 & 3.27 & 3.12 & 2.85 & 2.75 \\
\hline & Sharpe ratio & 2.03 & 2.14 & 2.15 & 2.22 & 2.06 & 1.98 & 2 & 1.99 & 1.94 & 2.14 & 2.12 \\
\hline & $\begin{array}{l}\text { Modified } \\
\text { Sharpe }\end{array}$ & 1.21 & 1.31 & 1.31 & 1.42 & 1.26 & 1.15 & 1.22 & 1.07 & 1.13 & 1.26 & 1.29 \\
\hline \multirow{4}{*}{ EW } & $\begin{array}{l}\text { Average } \\
\text { return }\end{array}$ & 7.78 & 7.56 & 7.44 & 8.34 & 7.55 & 6.85 & 7.57 & 7.87 & 7.05 & 7.42 & 6.71 \\
\hline & $\mathrm{SD}$ & 8.45 & 7.5 & 7.35 & 7.62 & 7.64 & 7.14 & 7.83 & 7.42 & 7.54 & 7.35 & 4.69 \\
\hline & Sharpe ratio & 0.92 & 1.01 & 1.01 & 1.09 & 0.99 & 0.96 & 0.97 & 1.06 & 0.94 & 1.01 & 1.43 \\
\hline & $\begin{array}{l}\text { Modified } \\
\text { Sharpe }\end{array}$ & 0.44 & 0.5 & 0.5 & 0.53 & 0.49 & 0.46 & 0.47 & 0.54 & 0.45 & 0.5 & 0.76 \\
\hline \multirow{4}{*}{ s.w. } & $\begin{array}{l}\text { Average } \\
\text { return }\end{array}$ & 7.92 & 7.87 & 7.83 & 8.15 & 7.87 & 7.62 & 7.88 & 7.98 & 7.69 & 7.83 & 7.86 \\
\hline & $\mathrm{SD}$ & 9.79 & 9.79 & 9.73 & 9.82 & 9.84 & 9.66 & 9.91 & 9.75 & 9.8 & 9.74 & 9.78 \\
\hline & Sharpe ratio & 0.81 & 0.8 & 0.8 & 0.83 & 0.8 & 0.79 & 0.79 & 0.82 & 0.78 & 0.8 & 0.8 \\
\hline & $\begin{array}{l}\text { Modified } \\
\text { Sharpe }\end{array}$ & 0.38 & 0.38 & 0.38 & 0.39 & 0.38 & 0.37 & 0.38 & 0.39 & 0.37 & 0.38 & 0.38 \\
\hline
\end{tabular}


Exhibit 14: Subperiod 2006-2010: Using unsmoothed returns and ETL as a risk metric

\begin{tabular}{|c|c|c|c|c|c|c|c|c|c|c|c|c|}
\hline \multirow[b]{2}{*}{$\begin{array}{l}\text { Asset } \\
\text { Allocation } \\
\text { Strategy }\end{array}$} & \multirow[b]{2}{*}{$\begin{array}{l}\text { Performance } \\
\text { Measure }\end{array}$} & \multirow[b]{2}{*}{$\begin{array}{l}\text { Stock- } \\
\text { Bond } \\
\text { Portfolio }\end{array}$} & \multicolumn{10}{|c|}{ Stock-bond portfolio including hedgefunds } \\
\hline & & & $\begin{array}{l}\text { Global } \\
\text { Hedge- } \\
\text { funds }\end{array}$ & $\begin{array}{l}\text { Convertible } \\
\text { Arb. }\end{array}$ & Distressed & $\begin{array}{l}\text { Equity } \\
\text { Hedge }\end{array}$ & $\begin{array}{l}\text { Equity } \\
\text { Market } \\
\text { Neutral }\end{array}$ & $\begin{array}{l}\text { Event } \\
\text { Driven }\end{array}$ & $\begin{array}{l}\text { Macro } \\
\text { Strategy }\end{array}$ & $\begin{array}{l}\text { Merger } \\
\text { Arb }\end{array}$ & $\begin{array}{l}\text { Relative } \\
\text { Value }\end{array}$ & All \\
\hline \multirow{4}{*}{$\operatorname{minSD}$} & $\begin{array}{l}\text { Average } \\
\text { return }\end{array}$ & 5.75 & 5.41 & 4.92 & 3.85 & 5.22 & 4.35 & 4.41 & 4.92 & 5.53 & 5.02 & 5.18 \\
\hline & $\mathrm{SD}$ & 3.18 & 2.9 & 3.72 & 3.87 & 3.28 & 2.34 & 3.64 & 3.15 & 3.32 & 3.08 & 2.44 \\
\hline & Sharpe ratio & 1.81 & 1.86 & 1.32 & 0.99 & 1.59 & 1.86 & 1.21 & 1.56 & 1.66 & 1.63 & 2.13 \\
\hline & $\begin{array}{l}\text { Modified } \\
\text { Sharpe }\end{array}$ & 1 & 1.08 & 0.38 & 0.34 & 0.67 & 1.3 & 0.3 & 0.87 & 0.7 & 0.67 & 1.07 \\
\hline \multirow{4}{*}{$\mathrm{RP}$} & $\begin{array}{l}\text { Average } \\
\text { return }\end{array}$ & 5.63 & 5.47 & 5.02 & 4.46 & 5.3 & 4.29 & 5.82 & 4.78 & 5.61 & 5.17 & 3.32 \\
\hline & $\mathrm{SD}$ & 4.09 & 4.2 & 4.11 & 4.09 & 4.05 & 3.03 & 3.98 & 3.96 & 3.76 & 4.09 & 3.08 \\
\hline & Sharpe ratio & 1.38 & 1.3 & 1.22 & 1.09 & 1.31 & 1.41 & 1.46 & 1.21 & 1.49 & 1.26 & 1.08 \\
\hline & $\begin{array}{l}\text { Modified } \\
\text { Sharpe }\end{array}$ & 0.43 & 0.41 & 0.32 & 0.27 & 0.39 & 0.52 & 0.5 & 0.39 & 0.45 & 0.36 & 0.27 \\
\hline \multirow{4}{*}{$\operatorname{maxSR}$} & $\begin{array}{l}\text { Average } \\
\text { return }\end{array}$ & 5.08 & 6.23 & 5.49 & 4.67 & 5.76 & 5 & 5.74 & 5.76 & 5.82 & 5.77 & 5.48 \\
\hline & $\mathrm{SD}$ & 3.93 & 3.06 & 3.5 & 3.84 & 3.4 & 2.96 & 3.21 & 3.3 & 3.26 & 3.22 & 2.46 \\
\hline & Sharpe ratio & 1.29 & 2.04 & 1.57 & 1.22 & 1.69 & 1.69 & 1.79 & 1.74 & 1.78 & 1.79 & 2.22 \\
\hline & $\begin{array}{l}\text { Modified } \\
\text { Sharpe }\end{array}$ & 0.31 & 1.13 & 0.6 & 0.3 & 0.59 & 0.7 & 0.78 & 0.95 & 0.81 & 0.89 & 0.8 \\
\hline \multirow{4}{*}{ RRT } & $\begin{array}{l}\text { Average } \\
\text { return }\end{array}$ & 3.65 & 3.32 & 3.56 & 3.13 & 3.4 & 3.68 & 3.41 & 3.57 & 4.01 & 3.37 & 2.91 \\
\hline & $\mathrm{SD}$ & 7.82 & 7.64 & 7.84 & 7.5 & 7.75 & 7.34 & 7.68 & 7.38 & 7.15 & 7.72 & 6.29 \\
\hline & Sharpe ratio & 0.47 & 0.43 & 0.45 & 0.42 & 0.44 & 0.5 & 0.44 & 0.48 & 0.56 & 0.44 & 0.46 \\
\hline & $\begin{array}{l}\text { Modified } \\
\text { Sharpe }\end{array}$ & 0.14 & 0.13 & 0.13 & 0.12 & 0.13 & 0.15 & 0.13 & 0.15 & 0.17 & 0.12 & 0.14 \\
\hline \multirow{4}{*}{ EW } & $\begin{array}{l}\text { Average } \\
\text { return }\end{array}$ & 7.51 & 6.6 & 5.75 & 5.89 & 6.6 & 6.55 & 6.68 & 6.59 & 7.36 & 6.77 & 3.56 \\
\hline & $\mathrm{SD}$ & 13.98 & 12.77 & 13.9 & 12.54 & 13.02 & 11.93 & 12.75 & 12.17 & 12.22 & 13.09 & 9.14 \\
\hline & Sharpe ratio & 0.54 & 0.52 & 0.41 & 0.47 & 0.51 & 0.55 & 0.52 & 0.54 & 0.6 & 0.52 & 0.39 \\
\hline & $\begin{array}{l}\text { Modified } \\
\text { Sharpe }\end{array}$ & 0.2 & 0.19 & 0.12 & 0.16 & 0.19 & 0.21 & 0.19 & 0.21 & 0.23 & 0.18 & 0.11 \\
\hline \multirow{4}{*}{ s.w. } & $\begin{array}{l}\text { Average } \\
\text { return }\end{array}$ & 7.61 & 7.32 & 7.02 & 7.07 & 7.32 & 7.3 & 7.34 & 7.31 & 7.58 & 7.38 & 7.29 \\
\hline & $\mathrm{SD}$ & 15.92 & 15.98 & 16.32 & 15.89 & 16.06 & 15.69 & 15.97 & 15.76 & 15.79 & 16.07 & 15.94 \\
\hline & Sharpe ratio & 0.48 & 0.46 & 0.43 & 0.44 & 0.46 & 0.47 & 0.46 & 0.46 & 0.48 & 0.46 & 0.46 \\
\hline & $\begin{array}{l}\text { Modified } \\
\text { Sharpe }\end{array}$ & 0.19 & 0.18 & 0.16 & 0.17 & 0.18 & 0.18 & 0.18 & 0.18 & 0.19 & 0.18 & 0.18 \\
\hline
\end{tabular}


Exhibit 15: Subperiod 2011-2016: Using unsmoothed returns and ETL as a risk metric.

\begin{tabular}{|c|c|c|c|c|c|c|c|c|c|c|c|c|}
\hline \multirow[b]{2}{*}{$\begin{array}{l}\text { Asset } \\
\text { Allocation } \\
\text { Strategy }\end{array}$} & \multirow[b]{2}{*}{$\begin{array}{l}\text { Performance } \\
\text { Measure }\end{array}$} & \multirow[b]{2}{*}{$\begin{array}{l}\text { Stock- } \\
\text { Bond } \\
\text { Portfolio }\end{array}$} & \multicolumn{10}{|c|}{ Stock-bond portfolio including hedgefunds } \\
\hline & & & $\begin{array}{l}\text { Global } \\
\text { Hedge- } \\
\text { funds }\end{array}$ & $\begin{array}{l}\text { Convertible } \\
\text { Arb. }\end{array}$ & Distressed & $\begin{array}{l}\text { Equity } \\
\text { Hedge }\end{array}$ & $\begin{array}{l}\text { Equity } \\
\text { Market } \\
\text { Neutral }\end{array}$ & $\begin{array}{l}\text { Event } \\
\text { Driven }\end{array}$ & $\begin{array}{l}\text { Macro } \\
\text { Strategy }\end{array}$ & $\begin{array}{l}\text { Merger } \\
\text { Arb }\end{array}$ & $\begin{array}{l}\text { Relative } \\
\text { Value }\end{array}$ & All \\
\hline \multirow{4}{*}{$\operatorname{minSD}$} & $\begin{array}{l}\text { Average } \\
\text { return }\end{array}$ & 2.98 & 2.8 & 2.23 & 3.34 & 2.98 & 2.93 & 3.23 & 2.98 & 3.28 & 3.7 & 3.47 \\
\hline & $\mathrm{SD}$ & 2.2 & 2.18 & 3.18 & 2.18 & 2.04 & 2.04 & 2.21 & 2.29 & 1.88 & 2.37 & 1.76 \\
\hline & Sharpe ratio & 1.35 & 1.29 & 0.7 & 1.53 & 1.46 & 1.44 & 1.46 & 1.3 & 1.74 & 1.56 & 1.97 \\
\hline & $\begin{array}{l}\text { Modified } \\
\text { Sharpe }\end{array}$ & 0.7 & 0.65 & 0.18 & 0.78 & 0.73 & 0.73 & 0.81 & 0.68 & 0.9 & 0.85 & 1.08 \\
\hline \multirow{4}{*}{$\mathrm{RP}$} & $\begin{array}{l}\text { Average } \\
\text { return }\end{array}$ & 3.8 & 3.39 & 3.43 & 3.49 & 3.47 & 2.9 & 3.54 & 3.02 & 3.82 & 3.33 & 2.01 \\
\hline & $\mathrm{SD}$ & 2.67 & 2.56 & 2.52 & 2.6 & 2.62 & 2.31 & 2.6 & 2.61 & 2.15 & 2.53 & 2.15 \\
\hline & Sharpe ratio & 1.42 & 1.32 & 1.36 & 1.35 & 1.32 & 1.26 & 1.36 & 1.16 & 1.78 & 1.31 & 0.94 \\
\hline & $\begin{array}{l}\text { Modified } \\
\text { Sharpe }\end{array}$ & 0.73 & 0.67 & 0.7 & 0.7 & 0.67 & 0.65 & 0.71 & 0.55 & 0.99 & 0.68 & 0.43 \\
\hline \multirow{4}{*}{$\operatorname{maxSR}$} & $\begin{array}{l}\text { Average } \\
\text { return }\end{array}$ & 3.56 & 3.82 & 3.53 & 4.08 & 3.48 & 3.01 & 3.58 & 2.89 & 3.93 & 2.95 & 3.3 \\
\hline & $\mathrm{SD}$ & 2.25 & 2.36 & 2.56 & 2.27 & 2.43 & 2.1 & 2.2 & 2.43 & 2.08 & 2.38 & 1.82 \\
\hline & Sharpe ratio & 1.59 & 1.62 & 1.38 & 1.8 & 1.43 & 1.43 & 1.63 & 1.19 & 1.89 & 1.24 & 1.81 \\
\hline & $\begin{array}{l}\text { Modified } \\
\text { Sharpe }\end{array}$ & 0.84 & 0.9 & 0.79 & 0.99 & 0.72 & 0.79 & 0.92 & 0.6 & 1 & 0.63 & 1.05 \\
\hline \multirow{4}{*}{ RRT } & $\begin{array}{l}\text { Average } \\
\text { return }\end{array}$ & 4.98 & 4.86 & 4.58 & 4.88 & 4.86 & 4.81 & 4.74 & 4.94 & 4.79 & 4.84 & 3.96 \\
\hline & $\mathrm{SD}$ & 5.17 & 5.04 & 4.98 & 5.14 & 5.09 & 4.91 & 5.11 & 5.1 & 4.42 & 5.1 & 4.01 \\
\hline & Sharpe ratio & 0.96 & 0.96 & 0.92 & 0.95 & 0.95 & 0.98 & 0.93 & 0.97 & 1.08 & 0.95 & 0.99 \\
\hline & $\begin{array}{l}\text { Modified } \\
\text { Sharpe }\end{array}$ & 0.41 & 0.42 & 0.39 & 0.41 & 0.42 & 0.43 & 0.4 & 0.42 & 0.48 & 0.41 & 0.45 \\
\hline \multirow{4}{*}{ EW } & $\begin{array}{l}\text { Average } \\
\text { return }\end{array}$ & 6.17 & 5.27 & 5.52 & 5.42 & 5.15 & 5.24 & 5.62 & 5.11 & 5.7 & 5.22 & 3 \\
\hline & $\mathrm{SD}$ & 8.12 & 7.42 & 7.23 & 7.59 & 7.66 & 7.09 & 7.59 & 7 & 7.12 & 7.35 & 5.02 \\
\hline & Sharpe ratio & 0.76 & 0.71 & 0.76 & 0.71 & 0.67 & 0.74 & 0.74 & 0.73 & 0.8 & 0.71 & 0.6 \\
\hline & $\begin{array}{l}\text { Modified } \\
\text { Sharpe }\end{array}$ & 0.32 & 0.3 & 0.33 & 0.3 & 0.28 & 0.3 & 0.32 & 0.3 & 0.33 & 0.3 & 0.25 \\
\hline \multirow{4}{*}{ s.w. } & $\begin{array}{l}\text { Average } \\
\text { return }\end{array}$ & 6.51 & 6.28 & 6.37 & 6.34 & 6.24 & 6.27 & 6.41 & 6.23 & 6.43 & 6.27 & 6.32 \\
\hline & $\mathrm{SD}$ & 9.33 & 9.39 & 9.32 & 9.44 & 9.47 & 9.28 & 9.45 & 9.24 & 9.29 & 9.37 & 9.35 \\
\hline & Sharpe ratio & 0.7 & 0.67 & 0.68 & 0.67 & 0.66 & 0.68 & 0.68 & 0.67 & 0.69 & 0.67 & 0.68 \\
\hline & $\begin{array}{l}\text { Modified } \\
\text { Sharpe }\end{array}$ & 0.29 & 0.28 & 0.28 & 0.28 & 0.27 & 0.28 & 0.28 & 0.28 & 0.28 & 0.28 & 0.28 \\
\hline
\end{tabular}

